\title{
Multidimensional Responsiveness: The Determinants of Legislators' Representational Priorities*
}

\author{
Jeffrey J. Harden ${ }^{\dagger}$
}

February 3, 2012

\begin{abstract}
Scholars of American politics typically conceptualize representation as mass-elite policy congruence, and in doing so have found several factors that hinder that relationship. These findings are at odds with the fact that American legislators often gain enough support to win re-election. I present an explanation for this puzzle by showing that legislators strategically provide four unique dimensions of representation to their constituents: policy, service, allocation, and descriptive. I unify these dimensions in a single theoretical model of legislators' priorities, then test it with data from survey experiments administered to 1,175 state legislators. I posit that legislators systematically emphasize some dimensions over others to further the goal of reelection. Given the constraints of resources and costs, legislators must choose their representational focus based on perceived electoral benefits. I find that institutional, district, and individual-level traits alter these resources, costs, and benefits, thereby driving legislators' strategic representational behavior.
\end{abstract}

Keywords: Representation · Policy congruence - Constituent service - Allocation · Descriptive representation $\cdot$ State legislators $\cdot$ Survey experiments

\footnotetext{
${ }^{*}$ Prepared for the $12^{\text {th }}$ annual State Politics and Policy Conference, February 16-18, 2012, Houston, TX.

${ }^{\dagger}$ Ph.D Candidate, Department of Political Science, University of North Carolina at Chapel Hill, 312 Hamilton Hall, CB \#3265, Chapel Hill, NC 27599, 919.600.9247, jjharden@unc.edu, http://jjharden.web.unc.edu/.
} 
The American political system typically judges politicians' performances in office through their handling of policy issues. From news stories and editorials on current debates to challengers' campaign advertising that cites specific votes or quotes from interviews, re-election-minded politicians must be constantly concerned with perceptions of their policy behavior. However, many generations of political scientists have found numerous obstacles to policy congruence- the expected positive relationship between constituent policy opinion and representatives' issue voting decisions. Indeed, policy congruence is not as strong as might be expected in an idealized representative democracy (see, for example Lax and Phillips 2012). The result is a key question for representation scholars: given this "democratic deficit," why is re-election common in American legislatures? Scholars provide several answers, including the numerous advantages afforded to incumbents both during and after election season.

However, these accounts also imply a more general explanation: that representation is complex and multifaceted, and thus responding to policy concerns is not the only element of the legislator's job. In particular, four unique dimensions of the concept stand out: (1) policy, or the link between citizen preferences and legislators' voting behavior, (2) service, which involves individual assistance to constituents who need help with government agencies, (3) allocation, or the securing of funding for the district, and (4) descriptive, which denotes a connection based on identity traits like gender or race. Scholars have been aware of these dimensions at least since Eulau and Karps (1977), but to date have not developed a theory explaining how legislators emphasize them when interacting with constituents.

In fact, a key problem for scholars of American politics is that the typical approach to studying representation is through a narrow examination of only one dimension, such as in the numerous studies on policy responsiveness. This is problematic for several reasons. First, as detailed below, legislators do not provide these dimensions in isolation, but rather must make tradeoffs between them. Second, there is likely to be overlap—or correlation—between the different dimensions, and so not accounting for each one ignores important complexity and could lead to misleading conclusions about the dimension of interest. Furthermore, even if those four components are entirely 
independent, recent research establishes that constituents hold diverse and systematic preferences over them (Griffin and Flavin 2011; Harden 2011b; Barker and Carman 2012). Thus, it is unrealistic to assume that all constituents want only one dimension of representation. In fact, legislators may have incentives to tailor their representational behavior to satisfy these demands.

I address the issue of legislators' supply of the dimensions of representation in this paper. Specifically, I develop a theory of legislators' representational priorities and test it empirically with original data. I posit that, given constraints from available resources and costs, legislators must choose their representational focus based on the perceived electoral benefits of each type. After detailing this theory, I test it with survey experiments that I administered to 1,175 American state legislators. I find that institutional, district, and individual-level traits alter resources, costs, and benefits, thereby driving legislators' strategic representational behavior.

\section{The Dimensions of Representation}

The need for work on additional dimensions of representation beyond policy is bolstered by the observation that American legislators typically win re-election despite a wide range of factors that obstruct the basic policy congruence relationship These include, among others, constituent knowledge and awareness (Verba and Nie 1972; Griffin and Flavin 2007) interest groups and bureaucracy (Lowi 1979; Jacobs and Shapiro 2000), partisan or legislators' own preferences (Mayhew 1974; Jacobs and Shapiro 2000), institutional factors (Lax and Phillips 2012), variance in electoral competition (Fiorina 1974; Griffin 2006), or constituency traits like population size and opinion heterogeneity (Hibbing and Alford 1990; Bailey and Brady 1998). In fact, Fenno's (1978) work shows that legislators may emphasize different types of representation to develop trust in the district, thereby giving them freedom in policy activities away from home. ${ }^{1}$

This observation that representation is more complex than just policy congruence dates back at least to Eulau and Karps (1977), who describe the four typologies of policy, service, allocation, and

\footnotetext{
${ }^{1}$ Of course, this does not mean that policy behavior is irrelevant. Indeed, scholars show that legislators' issue choices can have real electoral consequences (Canes-Wrone, Brady, and Cogan 2002; Hogan 2008). Nonetheless, the relative safeness of incumbent legislators suggests that many of those who are "out-of-step" still gain support through other means.
} 
symbolic (descriptive). However, while they warn against limiting scholarship to a single dimension, they do not develop or test a theory that encompasses the multiple dimensions. Furthermore, scholars' typical response to Eulau and Karps (1977) has been studies that still focus on only one dimension. Thus, there remains a need for theory that encompasses all four. Scholarly knowledge of representation should reflect the fact that legislators do not carry out any one dimension in isolation from the rest.

\subsection{Legislator Priorities}

Indeed, a consequence of this tendency to focus narrowly is not one large and integrated body of research on representation, but rather four relatively separate literatures on different components. This forces preferences into one dimension by assuming that constituents want, and thus legislators provide, the type of representation that is the topic of study. For instance, research on policy congruence assumes constituents are satisfied simply by a higher level of policy congruence, and so legislators should simply prioritize following district opinion in their voting behavior. ${ }^{2}$ The end result of this approach is many studies of representation that do not account for the findings of the others. Before providing a solution to this problem, I highlight key findings from these four literatures below.

\subsubsection{Policy Congruence}

Early policy responsiveness analyses find that partisanship provides the most structure to legislators' voting decisions, but that the constituency also matters (e.g., MacRae 1952; Patterson 1962; Wahlke, Eulau, Buchanan, and Ferguson 1962). Perhaps the most well-known work in this tradition is Miller and Stokes (1963), which made a considerable advancement on this front through the use of the American National Election Studies (ANES) data, disaggregated to the U.S. House district level. However, a key finding in that study is that the policy congruence relationship is not as strong in the U.S. Congress as might be expected in an ideal democracy. Several studies emerged in response to Miller and Stokes (1963) attempting to explain this, including the point

\footnotetext{
${ }^{2}$ I use the terms "policy congruence" and "policy responsiveness" interchangeably here. See Lax and Phillips (2012) for a discussion of differences between them.
} 
that legislators respond to their own perceptions of constituency opinion (e.g., Cnudde and McCrone 1966; Erikson, Luttbeg, and Holloway 1975) or that other factors can strengthen or weaken the relationship, such as electoral competition (Fiorina 1974; Griffin 2006), issue salience (Page, Shapiro, Gronke, and Rosenberg 1984), and constituency characteristics (Bullock and Brady 1983; Hibbing and Alford 1990).

A significant portion of more recent work continues to provide nuance to the policy congruence framework. For instance, several studies examine how the constituency fits in with other factors that drive legislative voting behavior, such as partisanship or legislators' own preferences (Levitt 1996; Ansolabehere, Snyder, and Stewart 2001) and ambition for higher office (Maestas 2000, 2003). Others demonstrate that legislators' responsiveness to constituent policy views weakens or strengthens by several factors, including heterogeneity or perceived changes in those views (Bailey and Brady 1998; Gerber and Lewis 2004; Harden and Carsey 2012; Kousser, Lewis, and Masket 2007). Finally, there is evidence that weak policy congruence has electoral consequences (CanesWrone, Brady, and Cogan 2002; Hogan 2008). In short, decades of research establish that policy is an important component of representation. However, the extent to which it becomes more or less important relative to other components is less clear, because this work focuses only on policy-based representation.

\subsubsection{Constituent Service}

Additional research shows that another important aspect of representation is the ability to listen to and address concerns from the constituency. Scholars find that variance in the amount of communication between the two is dependent on factors such as constituency size, communication medium, and cues from the constituent (Oppenheimer 1996; Freeman and Richardson 1996; Adler, Gent, and Overmeyer 1998; Butler and Broockman 2011). This work commonly distinguishes between the "normal vote," which is the electoral support a legislator can expect to receive due to shared partisanship with a segment of the district (Converse 1966), and the "personal vote," or "that portion of a candidate's electoral support which originates in his or her personal qualities, qualifications, activities, and record" (Cain, Ferejohn, and Fiorina 1987, 9). While several studies 
demonstrate that the personal vote can be a critical part of legislators' chances of getting reelected and serves as a source of the incumbency advantage, evidence is somewhat mixed as to whether service alone contributes to that benefit, at least at the Congressional level (cf. Johannes 1984; Cain, Ferejohn, and Fiorina 1987; Serra and Moon 1994).

Results are more clear at the state legislative level. Freeman and Richardson (1996) demonstrate that a number of factors influence the time state legislators spend on casework, including their own views of the importance of casework (a positive relationship), their views on its electoral benefit (positive), their opinion on limiting government spending (negative), and serving in a multimember district (positive). Serra and Pinney (2004) find evidence of electoral benefits to casework; service responsiveness corresponds to an increase in the probability of a constituent voting for the legislator and weakens the impact of issue positions on vote choice. Thus, representation through service can contribute to the development of a unique "homestyle" that allows for the development of trust in the district (Fenno 1978). However, the high cost of casework leads to the question of whether service is worthwhile compared to the other components of representation.

\subsubsection{Allocation Representation}

Along with service, allocation is another "district-centric" form of representation that scholars show can be beneficial to legislators. As Weingast $(1979,250)$ notes, "the representative seeks to be returned to office and his electoral fortunes are related to the benefits he brings home to his district" (see also Stein and Bickers 1995). Much of this work categorizes allocation as a part of the personal vote, similar to constituent service (e.g., Ansolabehere and Snyder 2000; Desposato and Petrocik 2003; Jacobson 2004). However, it is conceptually distinct from service because it provides benefits to the whole district, rather than just one constituent.

Recent work makes the case that legislators have clear electoral incentive to bring funding home. For example, Gamm and Kousser (2010) find that many bills in state legislatures are particularized in focus, aimed at benefiting individual districts rather than the state as a whole. Grimmer (2012) shows that representatives in districts with many of the other party's partisans focus less on policy issues, and instead on claiming credit for appropriations secured for the district. Using 2008 
data from U.S. House Appropriations, Lazarus (2010) finds that the number of earmarks and dollar amounts of distributive spending that representatives procure are positively related to demand-side factors, such as district ideology, unemployment, and size. However, he also finds that majority party status, seniority in the legislature, party leadership, and committee membership are also important. Thus, providing allocation as a form of representation is not costless, as many institutional factors could stand in the way of a legislator bringing funding home to the district.

\subsubsection{Descriptive Representation}

Scholarship indicates that gender and race play an important role through descriptive representation and in affecting provision of the other dimensions. Most relevant to the current study is the fact that research on descriptive representation is one of the few areas where more than one element of representation is combined; specifically, scholars typically look at descriptive representation through its effects on policy (e.g., Hero and Tolbert 1995; Meier, Juenke, Wrinkle, and Polinard 2005; Preuhs 2006). Other scholars point to the symbolic importance of descriptive representation. Women, for instance, tend to feel more "gender conscious" with regard to representation (Arceneaux 2001) Furthermore, being represented by someone who is similar instills feelings of efficacy and trust (Tate 2001; Lawless 2004). In certain cases, this can be strong enough to affect the connections between legislators and members of the group they represent or the political involvement of that subgroup (e.g., Gay 2002; Griffin and Keane 2006).

Past work also indicates that gender and race influence the other dimensions of representation. For example, women legislators take on roles as "problem-solvers" who emphasize community obligations and improving quality of life, while men are "advertisers" and "leaders" (see Kirkpatrick 1974; Diamond 1977; Thomas 1994; Swers 2002; Palmer and Simon 2006). Building from research on gender role socialization, Richardson and Freeman (1995) find that women state legislators receive more casework requests and perform more service than male colleagues. Scholars also find that African-American elites bring a district-centric focus to the office, prioritizing local problems that African-Americans typically face. Thomas (1992), for instance, demonstrates that women and African-American city council members are both more focused on service than their 
male and white counterparts. Similarly, Grose (2011) shows that African-American legislators focus on directing allocation funding to African-American constituents (see also Tate 2003).

\subsubsection{Uniting Four Literatures}

Overall, this work shows that each of these four dimensions are potentially important to legislators in providing representation to constituents. However, little is known about the circumstances that change the importance of each dimension. Past work has not allowed all four to compete in the same model. This is a problem because legislators with limited time and energy are not able to provide four types of representation at a maximum level. Instead, they likely have to make choices between them. Thus, studies of only one dimension miss important complexity, and do not give a true picture of what representation looks like in practice.

Below I address this problem by developing a more comprehensive theoretical model accounting for legislators' choices between the four components. My study also adds to the literature by testing the model with data from novel survey experiments administered to legislators. In doing so, I demonstrate that the choice of how to prioritize the dimensions of representation reflects strategic considerations by legislators.

\section{A Theory of Legislators' Representational Priorities}

I begin with the assumptions that legislators are driven by the goal of re-election and see representation as a means to that end. This leaves the problem of how best to represent the district to achieve that goal. As mentioned above, legislators must make choices in the face of two key constraints: (1) their resources (e.g., time, energy, and staff) and (2) the cost of each component of representation. This reflects a key difference between the supply side of representation and the demand side (e.g., Griffin and Flavin 2011; Harden 2011b). While there is no cost to constituents in demanding representation, legislators must choose how to expend finite resources to supply representation. I posit that they do so in a strategic manner.

Political scientists have typically referred to the term "strategic" as decision making in favor of a long-term goal at the expense of short-term gains (e.g., Austen-Smith 1987; Caldeira, Wright, and Zorn 1999). In this case, a naïve legislator would not pay attention to the tradeoffs between ex- 
penditures and electoral gains for a given representation activity. He or she would simply respond to any constituents without considering if the immediate benefit of that response is worth paying the cost in the long run. In contrast, I expect that strategic representatives carry out representation with keen attention to their resources, the costs, and long-term electoral gains.

Costs and benefits are important because they vary by each type of representation due to the number of constituents affected and the potential level of divisiveness. Policy responsiveness can impact many constituents, but can also lead to disagreement from the minority. Service is more likely to be universally positive, but because it requires more resources per person and is not typically publicized, only a limited number of constituents can be helped. Allocation has the potential for benefiting many people, but could be considered wasteful by some constituents who either disagree with the target of distributive funds or with the principle of government spending. Finally, descriptive representation could benefit a legislator if the endorsing group is large enough to make such identification electorally valuable. However, it could also alienate potential supporters who have negative feelings toward that group.

Another important element of this strategic model of representation is legislators' own ability to recognize situations that will benefit them and those that will not. Freeman and Richardson (1996) find that state legislators who believe casework helps them on Election Day conduct more service (see also Patterson 1990). This is suggestive of strategic behavior in a general sense. However, I posit that a strategic representative also makes case-by-case decisions about the extent to which they should expend resources in providing representation. Put differently, not all requests from constituents are likely to be viewed as equal. I expect strategic legislators to recognize this, and adjust their representational priorities accordingly.

Table 1 summarizes this process. Given the goal of re-election, legislator's seek ways of reaping electoral benefits, which ultimately dictates their priorities over the dimensions of representation. Constraining these benefits are both the amount of resources at their disposal as well as the costs of each dimension.

[Insert Table 1 here] 
The primary determinants of resources include the amount of staff available to help legislators, their salaries, and session length. Staff can help through taking on some responsibilities of the job for a legislator. For example, staff typically assist with research on policy issues or in managing input and requests for help from constituents. Salary dictates whether representatives can focus full-time on legislating or must hold a second career. This directly affects the amount of time they can put into the job. Similarly, session length also influences their level of work; those who are in session longer can spend more time doing the job. In short, legislators' resources directly impact their capacity to provide representation. Below I measure this factor through state legislative professionalism (Squire 2000).

Costs vary between the different components of representation based on the number of constituents affected. Responding to policy concerns through introducing or voting on a bill could affect most or all of the district. Thus, policy responsiveness is an effective way to represent many people at one time. Allocation and descriptive representation are similar-both are focused on providing representation to large groups of people in the district all at once. In contrast, constituent service is inherently a one-to-one relationship. A constituent contacts the legislator with a specific request and the legislator works to help that one constituent. In this sense, the per-constituent cost of providing service is higher than that of any of the other dimensions.

Benefits are also affected by how many constituents a given activity impacts, as well as whether that impact is divisive. Policy representation affects many, but also has the potential to be the most divisive, as salient issues typically have two or more points of view. Furthermore, policy change is typically a zero-sum game. If one side gets what it wants, the other side loses. Allocation also can benefit many constituents and is less likely to be zero-sum, but could still be divisive if different groups disagree on the best use of government money. Descriptive representation could be similar. If a legislator chooses to emphasize a descriptive trait, whether in a substantive or symbolic sense, constituents who share that trait will feel represented, but those in the out-group will not. In contrast, service is the least likely to generate a negative response, because legislators can provide assistance to any constituent without taking away from another. However, the positive 
affect created from performing constituent service is likely to be small because it is handled on an individual basis. Overall, if fewer constituents are affected and the representational activity is potentially divisive, the cost is higher and the benefit is lower.

Finally, beyond these general expectations, legislators' case-by-case perceptions of difficulty likely also impact how they provide representation, especially in a case that requires a high cost. If a legislator views a particular request or situation as difficult, the expected benefit declines. For example, while policy representation is typically more divisive, a given issue may not belegislators know when a specific policy question is more or less difficult to address. As another example, legislators also know when an individual request for service is more or less likely to be successful. I posit that in trying to generate positive affect from constituents at an efficient cost, legislators make individual, context-specific choices about where to distribute their effort.

In sum, this theoretical basis predicts that legislators are keenly aware of the four unique dimensions of representation and use them differently to promote their electoral fortunes. The costs and perceived benefits of one type are weighed against those of the others to produce the representational activities of the legislator. The final step is in moving from theory to hypotheses that can be tested, which I describe below.

\subsection{Hypotheses}

Testing this model empirically involves delineating the conditions under which resources, costs, and benefits of the dimensions of representation change. I posit that legislators carrying out strategic representation make choices about who and how to represent based on these considerations. In particular, I expect that institutional, district, and individual factors impact these conditions.

\subsubsection{Institutional Factors}

I expect the added resources of professionalized legislatures (e.g., staff, salary, and session length) to allow legislators to be more responsive than those without those resources. Professional legislators do not have to make as many difficult choices on who to represent or how much time they can devote to the constituency. Thus, I expect professional legislators to prioritize all forms of representation more highly than do citizen legislators. I also expect this positive effect to be 
strongest with constituent service. With more resources, obtaining the positive benefits of case work is a more realistic goal than it is for citizen legislators. Put differently, I expect that, given the need to make tradeoffs, citizen legislators reduce service before they compromise on other dimensions due to its high per-constituent cost.

H1 Professionalism $\rightarrow$ more policy, service, and allocation. Largest effect on service. (a) The added resources in professional legislatures allows representation to become a higher overall priority. (b) Resources particularly help offset the high per-constituent cost of conducting service, making casework a higher priority than it is in citizen legislatures.

Next, legislature size should exert a positive impact on the provision of allocation responsiveness. According to the "law of 1/n" (Weingast, Shepsle, and Johnsen 1981), distributive spending increases with chamber size. From a strategic perspective, as more members are allocating spending to their districts, a legislator has incentive to spend, and thus claim credit for his or her own district projects. This enhances the electoral benefits of allocation. Increases in the number of seats in the legislature means more districts share costs, providing the incentive to draw from common pool resources. ${ }^{3}$

$\mathrm{H} 2$ Legislature size $\rightarrow$ more allocation. Larger legislatures correspond with lower costs of allocation, making it a higher priority as size increases.

\subsubsection{District Characteristics}

I also expect district-level demand for the various types of representation to play a role in this process. Harden $(2011 b)$ finds that economically-disadvantaged constituents prefer district-centric types of representation (service and allocation) compared to the economically-advantaged because poor constituents are more likely rely on government assistance (see also Griffin and Flavin 2011). I expect that fulfilling these demands increases the benefits of service and allocation, and thus legislators in poor districts focus more on those dimensions than do legislators in wealthy districts.

\footnotetext{
${ }^{3}$ However, as Chen and Malhotra (2007) and others find, there is reason to expect this result to be different in upper and lower chambers (see also Primo 2006; Primo and Snyder 2008). I tested this conditional hypothesis with the data described below and found no support.
} 
$\mathrm{H} 3$ Lower district median income $\rightarrow$ more service and allocation. Legislators representing poorer districts make service and allocation representation a higher priority than do those in wealthy districts because poor constituents demand increased attention to those types.

Next, I posit that the racial make-up of the district influences descriptive representation. In particular, I expect that African-American legislators focus more on descriptive representation when there are more black constituents in their district. Black legislators in districts with majority blacks populations have stronger mandates to represent the African-American voice in government, and likely feel a stronger symbolic attachment to the black community than those in districts with a small proportion of African-Americans. Thus, the benefits of focusing on descriptive representation increases with the proportion of blacks in the district.

H4 District percent black $\rightarrow$ more descriptive from black legislators. Black representatives can reap more benefits from identifying with constituents of their same race when there are more black constituents in their district. Thus, prioritization of descriptive representation increases as the percentage black in the district increases.

I also expect district magnitude to influence representational priorities by making service and allocation less important. The presence of additional representatives in the district provides incentive to avoid the high per-constituent cost of service, because casework could be performed by other representatives. It also makes credit-claiming for district projects more difficult than in single-member districts, because credit is likely to be split between all legislators in the district. This decreases the potential benefit of allocation representation.

H5 Multimember districts $\rightarrow$ less service and allocation. Multiple representatives in the district provide incentive to avoid the high per-constituent cost of service and make credit-claiming for allocation more difficult than in single-member districts. Thus, service and allocation receive lower prioritization in multimember districts. 


\subsubsection{Individual Traits}

Electoral vulnerability likely plays a role in determining the costs and benefits of the various types of representation. A great deal of work in American politics addresses the "marginality hypothesis," which states that legislators facing competition are more responsive to their constituents with respect to policy. Support for this assertion is mixed. ${ }^{4}$ I expect that competition affects different types of responsiveness in different ways. Similar to the idea of heresthetic change (Riker 1986), legislators facing recent close challenges have incentive to avoid the policy dimension and emphasize the less divisive representational activities (see also Grimmer 2012). I expect these legislators to focus less on policy representation and more on service and allocation responsiveness. In contrast, the potential cost of divisiveness decreases with less competition; safe legislators can afford to focus on policy because a larger proportion of the district is likely to be supportive.

H6 Electoral competition $\rightarrow$ less policy, more service and allocation. Electorally vulnerable legislators benefit from focusing on the less divisive components, and thus prioritize service and allocation higher and policy lower than do legislators in safe seats.

Next, I posit that, due to their minority status, women, African-American, and Latino legislators prioritize descriptive representation more than do the majority men and whites. Additionally, as literature described above explains, women legislators are more concerned with caretaking and problem-solving and racial minority legislators view their roles in government as district-centric providers to their constituents. Thus, I expect women to prioritize service more highly than do men and minority legislators to prioritize service and allocation more highly than do whites.

$\mathrm{H} 7$ Minority legislator $\rightarrow$ more descriptive. Gender and/or race is most salient to women and racial minorities, and thus they prioritize responsiveness to women and racial minorities, respectively, more highly than do men and/or whites.

H8 Minority legislator $\rightarrow$ more service and/or allocation. Women legislators focus on caretaking and problem-solving, and thus focus more on service than do men. Minority legisla-

\footnotetext{
${ }^{4}$ See, for example, MacRae (1952), Fiorina (1974), Sulkin (2005), and Griffin (2006).
} 
tors view their roles in government as district-centric providers, leading to a higher prioritization of service and allocation.

Finally, I posit that legislators make case-by-case strategic decisions about representational priorities. In light of the constraints of limited resources and costs of providing representation, legislators likely choose when they can be effective in specific situations, and prioritize those cases. In other words, they place value on increasing the number of constituents helped, and thus work to help the easier problems and issues first. Additionally, I expect that this relationship is strongest when dealing with constituent service requests, because casework involves the highest per-constituent cost. Consequently, a service request only receives priority when a legislator feels it is very likely within his or her capabilities to solve it.

H9 Chance of satisfying the constituent $\rightarrow$ higher priority. (a) Legislators place a higher priority on constituent questions that they believe they have a greater likelihood of satisfying. (b) This effect is larger for constituents asking for service.

\section{Research Design}

The data used to test these hypotheses come from a survey administered online to state legislators from January-May 2011. I e-mailed the survey link to 6,678 legislators from 46 states, or about $90 \%$ of the population of 7,382 state legislators in $2011 .^{5}$ The e-mail asked potential respondents to take an anonymous survey "about the job of a state legislator," and specifically mentioned that either the legislator or a staff member could provide the response. 1,362 recipients clicked on the link, and 1,175 respondents from all 46 states in the recruitment e-mail completed the survey. ${ }^{6}$ Of those completions, $298(\approx 25 \%)$ reported being a member of the legislator's staff. Each respondent answered a total of 10 questions, and the median completion time was five minutes.

As shown in Table 2, the sample is reasonably representative of the population of state legislators, though there was some underrepresentation of minorities. Women, Democrats, and members

\footnotetext{
${ }^{5}$ I was limited to only those legislators whose e-mail addresses were publicly available. In four states-Idaho, South Carolina, South Dakota, and Texas-e-mail addresses were unavailable or contacting legislators required a valid physical mailing address in the legislator's district.

${ }^{6}$ Thus, the usable sample reflects an $18 \%$ response rate, or $16 \%$ of the population of state legislators in 2011.
} 
of the lower chambers were slightly overrepresented compared to their respective population proportions, while blacks and Latinos were underrepresented. ${ }^{7}$ To compensate for these problems, I constructed a survey weight for all analyses described below through a raking procedure designed to match sample marginals to population marginals with respect to party, gender, race, and chamber (see Kalton and Flores-Cervantes 2003).

[Insert Table 2 here]

\subsection{Experimental Manipulations and Questions}

The survey presented respondents with two sets of experimental manipulations: a traditional survey experiment and a list experiment. All respondents completed the survey experiment first, then the list experiment. See the appendix for the full text of the survey instrument.

\subsubsection{Constituent E-mail Experiment}

In the first experimental manipulation, respondents saw three hypothetical e-mails from a constituent, presented in random order. The topic of each message signaled a policy, service, or allocation question. The policy question was on public education, the service question requested assistance in getting a driver's license, and the allocation question asked about funding to repair roads in the district. Each message was also crossed by the constituent's gender and race via the name; specifically, I used traditionally white, black, and Latino/a male and female names to signal these traits. ${ }^{8}$ Thus, there were 18 experimental conditions $(3$ message types $\times 2$ genders $\times 3$ races), of which each respondent viewed three.

After viewing each of the three e-mail messages, respondents answered two questions about the message. The first was a rating of the priority respondents would assign to that e-mail if it were sent to them from a constituent. This measure ranged from 0-100, with 0 being the lowest priority, 50 representing "average priority" and 100 being the highest priority. The second question asked respondents to rate the likelihood that they could satisfy the constituent's request on a 1-6 scale, with 1 corresponding to "very unlikely" and 6 corresponding to "very likely."

\footnotetext{
${ }^{7}$ See the appendix for a complete report of state-level response rates.

${ }^{8}$ Lists of names came from Fryer and Levitt (2004) and the sources therein. Different names were used in each message type so that a respondent never saw the same name more than once. See the appendix for the complete list.
} 


\subsubsection{List Experiment}

In the constituent e-mail experiment, my expectations about descriptive representation are tested only through the constituent's name at the bottom of the message, rather than the entire message content as with the other three dimensions. Thus, I also employed a list experiment as an additional test of those expectations. The list experiment provides a means of eliciting answers to sensitive items in a way that protects anonymity (Miller 1984). Respondents are randomly divided into treatment and control groups, presented with a list of items, and asked to provide the number of those items that apply to them (but not which items). The control group receives a list of nonsensitive items, while the treatment group receives the same non-sensitive items plus one sensitive item. Differences in the average number of items between the two groups can then be attributed to the sensitive item.

In this case, the non-sensitive items I presented (in random order) were five potential tasks of a legislator. Three described policy, service, and allocation representation and two described additional tasks. Respondents in the control group saw only these five items, and were asked to respond with how many applied to them in their job as a legislator.

(1) Learning about constituents' opinions in order to better represent their views.

(2) Helping constituents who have personal problems with government agencies.

(3) Making sure the district gets its fair share of government money and projects.

(4) Preparing to run for higher office, such as Governor or the U.S. Congress.

(5) Representing the views of interest groups.

I anticipated that the latter two items would less popular, and thus induce negative correlation with the first three. This is a common technique in list experiments designed to keep the average number of items in the control group from becoming too high (see Imai 2011). Respondents in the treatment group saw (in random order) the five items above and the sensitive item in their lists:

(1) Learning about constituents' opinions in order to better represent their views.

(2) Helping constituents who have personal problems with government agencies.

(3) Making sure the district gets its fair share of government money and projects. 
(4) Preparing to run for higher office, such as Governor or the U.S. Congress.

(5) Representing the views of interest groups.

(6) Making sure that people who are of the same gender or race as you have their voices heard in government.

As I discuss in greater detail below, differences between these two groups produces an estimate of the proportion of the population of legislators who view descriptive representation (as defined by this item) as part of their job.

\subsection{Estimation Strategies}

Testing the hypotheses with these experiments involves two different estimation strategies: a linear generalized estimating equation (GEE) model for the constituent e-mail experiment and difference-in-means and item count regression for the list experiment.

\subsubsection{Constituent E-mail Experiment}

The main dependent variable of interest in the constituent e-mail experiment is the priority rating. My strategy in testing the hypotheses listed above is to use a linear model of this measure as a function of indicators for each treatment and their interactions with relevant legislator traits, as shown below.

$$
\begin{aligned}
\text { Priority Rating }= & \gamma_{1}(\text { Treatment } 1)+\ldots+\gamma_{t}(\text { Treatment } t)+\beta_{1}(\text { Legislator Trait })+ \\
& \beta_{2}(\text { Treatment } 1 \times \text { Trait })+\ldots+\beta_{t}(\text { Treatment } t \times \text { Trait })+\varepsilon
\end{aligned}
$$

These traits capture the institutional, district, and individual factors discussed above. ${ }^{9}$ I use this interaction design because my interest is not in the average effect of each treatment on the priority rating, but on how those effects change as a function of the key respondent traits. I use a generalized estimating equation (GEE) model with exchangeable correlation to account for the repeated measurements in the survey design—each respondent viewed and answered the questions for three

\footnotetext{
${ }^{9}$ The appendix contains independent and dependent variable descriptions and summary statistics and a correlation matrix of the independent variables.
} 
separate treatments (see Liang and Zeger 1986). ${ }^{10}$

Importantly, I chose to estimate these models separately for each independent variable of interest. Another option is to put all of the variables and their interactions with each treatment in a single model. I present results from separate, smaller models because the literature on interaction terms makes clear that the large model approach is essentially uninterpretable. It has more than 30 variables, with half of them being interaction terms (Jaccard and Turrisi 2003; Brambor, Clark, and Golder 2006). Of course, this strategy opens the door to the issue of underspecification. While treatments were randomly assigned to respondents, the institutional, district, and individual variables - many of which are likely to be correlated - were not, and thus there is the potential for omitted variable bias. However, in this case the two approaches produce findings that are largely consistent; see the appendix for both sets of results. Thus, I use the smaller models to mitigate the “curse of dimensionality" from large models (see Achen 2002).

\subsubsection{List Experiment}

The typical approach to modeling list experiment data is to conduct a simple difference-inmeans test between the treatment and control groups. This approach is helpful, but does not rule out the possibility of omitted variable bias from pre-treatment covariates or allow for more complex hypothesis testing. Imai's (2011) item count regression (ICT) solves that problem by allowing analysts to conduct multiple regression analysis with list experiment data. The ICT method uses a non-linear least squares estimator to model the treatment and control group means conditional on a set of covariates. In the current study, I use it to assess whether apparent racial differences between treatment and control are due to other respondent factors and to examine how these racial differences change as a function of district racial make-up.

\footnotetext{
${ }^{10}$ Though a series of simple mean comparisons are one option for testing these interactive hypotheses, I use a regression framework to improve efficiency of the estimates. Freedman (2008) contends that the use of regression on experimental data is problematic because randomization does not guarantee unbiasedness in the covariates of a regression model. However, he also shows that this is issue is trivial in sample sizes larger than 500. Thus, with nearly 800 usable cases, I use regression to improve efficiency.
} 


\section{Results}

I present and discuss select results from the constituent e-mail experiment first and the list experiment second. Complete results are given in the appendix.

\subsection{Constituent E-mail Experiment}

In place of tables, I present results graphically with predicted values of the priority rating based on different experimental condition/respondent trait combinations (see the appendix for results in table form). Before presenting the main results, I briefly assess the baseline treatment effects for descriptive purposes. I present these baseline models graphically in the appendix. They show that, on average, respondents prioritize the service condition over policy and policy condition over allocation, though these differences are somewhat small in magnitude and not statistically significant. Additionally, differences between the different gender and racial names show only small differences in average priority rating. However, my central concern is identifying factors that produce changes in these baseline preferences. I turn to this task next.

The complete GEE results are presented in table form in the appendix. As I detail below, those results show support for H1 (professionalism), H5 (multimember district), H6 (electoral competition), and H9 (chance of satisfying the constituent). There is little or no support for the other hypotheses. Specifically, the interactions between the following variables and the relevant treatment conditions and are either small in magnitude and/or statistically nonsignificant: chamber size $(\mathrm{H} 2)$, district median income $(\mathrm{H} 3)$, and the gender and race of the legislator ( $\mathrm{H} 7$ and $\mathrm{H} 8)$.

Thus, in the interest of space, I present results graphically for only those variables that produce substantively meaningful differences in the average priority rating. Figure 1 shows several graphs depicting tests of $\mathrm{H} 1, \mathrm{H} 5, \mathrm{H} 6$, and $\mathrm{H} 9$. The $\mathrm{y}$-axes plot predicted values of the priority rating as a function of various experimental condition and legislator trait combinations, which are listed on the x-axes. An asterisk above two same-shaded bars indicates a statistically significant difference between them ( $p<0.05$, two-tailed). The ratings are calculated with the white male constituent condition. 


\section{[Insert Figure 1 here]}

Panel (a) shows that, as predicted by H1a, legislators in highly-professionalized states rate all three conditions higher, on average, than do citizen legislators. There is also support for H1b: the difference between professional and citizen legislators is considerably larger in the service condition (20 points) than it is in the policy or allocation conditions (5 points each). Furthermore, the difference in the service is substantively large-about one-fifth of the $0-100$ priority scaleand statistically significant $(p<0.05)$.

Next, panel (b) displays results for legislators in single member and multimember districts. Although differences between average ratings of the two groups in the allocation condition are negligible, there is a moderate difference ( 5 points) between them in the service condition. In line with $\mathrm{H} 5$, legislators representing multimember districts rate service as a lower priority, on average, than do those in single member districts.

Panel (c) displays the effects of electoral competition (H6), comparing a legislator who received $50 \%$ of the vote in the last election to one who received $100 \%$. Note that there is partial support for H6 in these two groups' average ratings of the policy condition. Legislators who faced difficult competition in the past rate policy 6 points lower, on average, compared to those legislators who ran uncontested $(p<0.05)$. Legislators in competitive districts also rated the service condition 4 points higher than they rated the policy condition, on average, though this effect is not statistically significant.

Panel (d) shows the effect of legislators' assessment of their chance of satisfying the constituent in the message. That graph shows strong support for H9a. Legislators who thought they were "very likely" to satisfy the constituent prioritize that e-mail substantially higher, on average, than do those who thought they were "very unlikely" to satisfy the constituent. Indeed, this difference amounts to at least 30 points on the priority scale, depending on the treatment message ( $p<0.05$ in all three conditions). Additionally, the values next to each pair of bars on the graph, which indicate the difference between the two bars, suggest that there is some support for H9b. The difference in priority ratings between the "very likely" and "very unlikely" categories for each condition is 
larger in the service condition (39 points) than in either of the other two (30 for policy, 33 for allocation).

Though the likelihood of satisfying the request exerts a strong effect on the priority rating, it is less clear exactly how legislators actually decide if they are unlikely or likely to be able to help. From the theory described above, I expect that legislators make such an assessment based on their available resources: those with more resources are more confident in their chances of successfully helping the constituent. I test this in Figure 2, which displays results from an ordered logistic regression model predicting responses to the likelihood of satisfying question as a function of treatment indicators and their interactions with professionalism. ${ }^{11}$ The graphs plot the predicted probabilities of a "likely" or "very likely" response (black lines) and the predicted probabilities of an "unlikely" or "very unlikely" response (gray lines) in the three different conditions.

\section{[Insert Figure 2 here]}

Note that in all three panels the predicted probability of being able (unable) to satisfy the request increases (decreases) as professionalism increases. Thus, as expected, legislators with more resources are more confident, on average, that they can help their constituents. Furthermore, as before the effect is the strongest in the service condition (panel b). The probability of a legislator feeling "likely" or "very likely" to be able to help a constituent service request increases from about $50 \%$ to $85 \%$ across the range of professionalism. This is consistent with the fact that service carries the highest per-constituent cost, and thus legislators in professionalized legislatures are most likely to be successful with constituent service.

In summary, the constituent e-mail experiment provides some support for the theoretical model described above. Consistent with my expectations of strategic provision of representation, results indicate that professionalism, multimember districts, electoral competition, and the chance that a legislator can satisfy a constituent request influences priorities over the dimensions of representation. Professional legislators prioritize the dimensions more highly, on average, compared to

\footnotetext{
${ }^{11}$ See the appendix for complete model results. In this case, to address the repeated measurements within respondents I computed bootstrap cluster standard errors (BCSE, see Harden 2011a).
} 
citizen legislators, with a particularly large difference in service requests. Legislators in multimember districts place a slightly lower priority on service than do those in single member districts. Electorally-vulnerable representatives make policy a lower priority than their counterparts in safe seats. Finally, beyond its direct effect, professionalism also exerts an indirect effect on representational priorities. Professional legislators are more confident in their chances of satisfying concerns, and a constituent's request gets prioritized much more highly when legislators feel they have a good chance of satisfying it, especially when it is a request for constituent service.

\subsection{List Experiment}

The list experiment data provide a test of $\mathrm{H} 7$, which states that minority legislators prioritize descriptive representation more than do whites. This hypothesis would be supported if women and/or black legislators affirmed the sensitive item at a higher rate than did white males. These data also allow for a direct test of $\mathrm{H} 4$ - that the importance of descriptive representation increases for black legislators elected in districts with high concentrations of black constituents. Support for this hypothesis would come from a larger difference between blacks in treatment and control who represent majority-black districts compared to the difference between blacks in the two groups who represent majority-white districts.

I begin this analysis with simple difference-in-means testing. Table 3 presents the mean number of items as well as differences in means between treatment and control by gender and race. Notice that the difference between treatment and control is statistically significantly different at the 0.05 level for both men and women. However, in contrast to H7, the difference in means is lower for women (0.26) than it is for men (0.37).

[Insert Table 3 here]

Differences along racial lines strongly support H7. The difference in mean number of items between whites in treatment and control is a statistically significant 0.31 , suggesting that about 3 in 10 white legislators consider descriptive representation as one of their responsibilities among the options given in the question. In contrast, for blacks in the sample the number jumps to a difference 
of nearly 1, which implies that almost all black legislators count descriptive representation among their duties from the options given. Due to the small sample size of black respondents, this estimate has a large standard error (the lower 95\% confidence bound is 0.52). But it is still statistically significantly different from the estimate for whites ( 0.31 , upper $95 \%$ confidence bound of 0.43$)$. In short, there is support for $\mathrm{H} 7$ with resepct to African-American legislators, but not with women.

Although informative for testing H7, the difference-in-means approach does not allow for control variables or the testing of an interactive hypothesis like H4. Imai's (2011) ICT method facilitates both in a multiple regression framework. ${ }^{12}$ Table 4 presents ICT results with the following covariates: gender, race, party, seniority, electoral competition, district percent black, district median income, multimember district, and state legislative professionalism. The key independent variable of interest is an interaction between the indicator for black legislators and district percent black. In line with $\mathrm{H} 4$, I expect the coefficient on that interaction to be positive in the treatment group and negative in the control, indicating that the difference between blacks in treatment and control becomes larger as the percentage of blacks in the district increases. This model also allows for a test of whether a gender effect appears after controlling for other variables. From H7, I expect the indicator for female legislators to produce a positive coefficient in the treatment group and a negative estimate in the control group.

[Insert Table 4 here]

Table 4 shows support for H4. The coefficient on the interaction term Black Legislator $\times$ District \% Black is positive in the treatment group and negative in the control group. However, it is only statistically significant in the control group. Thus, more interpretation is needed to assess whether the relationship is substantively meaningful. As before, $\mathrm{H} 7$ is not supported. Counter to expectations, the coefficient on female legislator is negative in the treatment group and positive (and statistically significant) in the control group.

\footnotetext{
${ }^{12}$ Imai (2011) also provides a means of testing for the presence of a design effect-whether respondents in the treatment group responded differently to the non-sensitive items than did those in the control group. These data show no evidence of a design effect.
} 
Figure 3 shows the substantive implications of these results. Panel (a) presents the estimated proportion of men and women legislators affirming the sensitive item after controlling for the other covariates. Panel (b) plots the estimated proportion of white legislators (gray line) and black legislators (black line) affirming the sensitive item across the observed range of district percent black, with asterisks on the line where the estimate for blacks is statistically significantly different from that for whites. The histograms at the bottom of panel (b) show the distribution of district percent black for districts with a white legislator (light gray) and districts with a black legislator (dark gray).

\section{[Insert Figure 3 here]}

Beginning in panel (a), the results show no support for $\mathrm{H} 7$ with respect to women. Similar to the difference-in-means results, the estimated proportion of women legislators affirming the sensitive item is statistically significant at the 0.05 level after controlling for other factors. However, the estimate for men is also significant, and slightly larger than the estimate for women.

Panel (b) shows considerable support for H4. Notice that the estimated proportion of white legislators affirming the sensitive item increases only slightly (about 4\%) across the observed range of district percent black. In contrast, the estimated proportion for black legislators increases dramatically, from an estimate of less than $10 \%$ affirming the sensitive item in a district with $1 \%$ black constituents to about $99 \%$ in districts that are $90 \%$ blacks. The histograms show that most black legislators represent heavily black districts and most white legislators represent districts with small proportions of blacks. Nonetheless, both black and white legislators still cover a wide range: from 0 to $71 \%$ among whites and less than $1 \%$ to $90 \%$ among blacks. Finally, the asterisks show the difference between whites and blacks is statistically significant once the percentage black in the district reaches approximately $50 \%$.

In sum, by using ICT regression rather than only the difference-in-means approach, I show that the racial effect is robust to several control variables and that there exists a key interactive effect. Black legislators emphasize the descriptive dimension more as the group that they descriptively represent becomes larger, and understate that dimension as the group size decreases. This strong 
interaction may provide an explanation for the lack of differences based on gender. Unlike with race, all districts have about $50 \%$ women, and thus there is no variation to produce changes in the emphasis on descriptive representation.

\section{Conclusions}

Most studies on representation in American politics focus on some form of mass-elite policy congruence, in which the presence or absence of representation depends on whether a legislator follows constituent policy preferences in his or her voting behavior. The fact that legislators typically win re-election in spite of many obstacles to this policy congruence relationship implies that representation is inherently more complex. Indeed, conceptualizing representation solely as responsiveness to policy ignores at least three other important dimensions: service, allocation, and descriptive. However, even those studies of the non-policy dimensions typically still focus narrowly on just one. Here I unify all four dimensions of representation in a single theoretical model of legislators priorities, and test that model on original data from a survey of state legislators. I posit that legislators emphasize the different dimensions in a strategic manner to further the goal of re-election. Given the constraints of limited resources and costs of representation, legislators must choose their representational focus based on the perceived benefits of each type. I find that institutional, district, and individual-level traits alter these costs, benefits, and resources, thereby driving legislators strategic representational behavior.

Specifically, the constituent e-mail experiment results indicate that legislators in professionalized institutions, which benefit from increased resources, prioritize service more highly than do citizen legislators. In contrast, legislators in multimember districts rate service as less of a priority because other legislators in their district are available to help, allowing them to avoid the high per-constituent cost of casework. Legislators in competitive districts tend to de-emphasize policybased representation compared to their colleagues in safe seats. A strategic element appears again in legislators' own assessments of their chance of satisfying constituent questions. When they feel they are likely to be able to help, legislators prioritize the constituent's message higher than when they feel unable to help. This is especially true in conducting constituent service, where the cost 
is high. Finally, I show evidence of strategy in focusing on descriptive representation through a list experiment. I find that black legislators prioritize descriptive representation more highly when most of their constituents are black, and less so when the district contains only a small proportion of blacks.

Nonetheless, some hypothesized patterns did not bear out in the empirical evidence. The strong effect of legislators' own assessment of satisfying the constituent implies that a considerable portion of the strategic element is done on a case-by-case basis. While some institutional and district factors exert influence, it may be that legislators develop a sharp ability to recognize which constituent questions are worth their time and which are not.

Overall, this study shows the importance of conceptualizing representation as multidimensional. While policy congruence is undoubtedly a crucial element in the representative-constituent relationship, the fact that legislators exhibit systematic and meaningful variance in priorities over policy, service, allocation, and descriptive representation indicates that the job is much more complex than simply voting in line with district preferences. Normatively, this study shows a benefit of the trend toward increasingly professionalized legislatures in the American states, as it suggests that legislators in professional states use the additional resources to make constituents a higher priority. However, this research also provides evidence of a representational disequilibrium. Recent work shows that minority and economically-disadvantaged constituents prefer district-centric representation (i.e., service and allocation) more than do whites and the economically-advantaged. Some null findings from this study indicate that legislators do not meet this demand. Thus, representatives may not only be "out-of-step" due to weak policy congruence, but through the other dimensions of representation as well. 


\section{References}

Achen, Christopher H. 2002. "Toward a New Political Methodology: Microfoundations and ART." Annual Review of Political Science 5(1): 423-450.

Adler, E. Scott, Chariti E. Gent, and Cary B. Overmeyer. 1998. "The Home Style Homepage: Legislator Use of the World Wide Web for Constituency Contact." Legislative Studies Quarterly 23(4): 585-595.

Ansolabehere, Stephen D., and James M. Snyder. 2000. "Valence Politics and Equilibrium in Spatial Election Models." Public Choice 103(3-4): 327-336.

Ansolabehere, Stephen, James M. Snyder, and Charles Stewart. 2001. "Candidate Positioning in U.S. House Elections.” American Journal of Political Science 45(1): 136-159.

Arceneaux, Kevin. 2001. “The 'Gender Gap' in State Legislative Representation: New Data to Tackle an Old Question.” Political Research Quarterly 54(1): 143-160.

Austen-Smith, David. 1987. "Sophisticated Sincerity: Voting Over Endogenous Agendas." American Political Science Review 81(4): 1323-1329.

Bailey, Michael, and David W. Brady. 1998. "Heterogeneity and Representation: The Senate and Free Trade." American Journal of Political Science 42(2): 524-544.

Barker, David C., and Christopher Jan Carman. 2012. Political Representation in Red and Blue America: How Our Cultural and Ideological Differences Change the Way Politicians Listen. New York: Oxford University Press.

Brambor, Thomas, William Roberts Clark, and Matt Golder. 2006. "Understanding Interaction Models: Improving Empirical Analyses.” Political Analysis 14(1): 63-82.

Bullock, Charles S., and David W. Brady. 1983. "Party, Constituency, and Roll-Call Voting in the U.S. Senate." Legislative Studies Quarterly 8(1): 29-41.

Butler, Daniel M., and David E. Broockman. 2011. "Do Politicians Racially Discriminate Against Constituents? A Field Experiment on State Legislators." American Journal of Political Science 55(3): 463-477.

Cain, Bruce, John Ferejohn, and Morris P. Fiorina. 1987. The Personal Vote: Constituency Service and Electoral Independence. Cambridge, MA: Harvard University Press.

Caldeira, Gregory A., John R. Wright, and Christopher Zorn. 1999. "Sophisticated Voting and Gate-Keeping in the Supreme Court.” Journal of Law, Economics, \& Organization 15(3): 549572.

Canes-Wrone, Brandice, David W. Brady, and John F. Cogan. 2002. "Out of Step, Out of Office: Electoral Accountability and House Members' Voting." American Political Science Review 96(1): 127-140.

Chen, Jowei, and Neil Malhotra. 2007. "The Law of $k / n$ : The Effect of Chamber Size on Government Spending in Bicameral Legislatures." American Political Science Review 101(4): 655-674.

Cnudde, Charles F., and Donald J. McCrone. 1966. "The Linkage Between Constituency Attitudes and Congressional Voting Behavior: A Causal Model." American Political Science Review 60(1): 66-72.

Converse, Philip E. 1966. "The Concept of the Normal Vote." In Elections and the Political Order, ed. Angus Campbell, Philip E. Converse, Warren E. Miller, and Donald E. Stokes. New York: 
Wiley.

Desposato, Scott W., and John R. Petrocik. 2003. "The Variable Incumbency Advantage: New Voters, Redistricting, and the Personal Vote." American Journal of Political Science 47(1): 1832.

Diamond, Irene. 1977. Sex Roles in the State House. New Haven, CT: Yale University Press.

Erikson, Robert S., Norman R. Luttbeg, and William V. Holloway. 1975. “Knowing One's District: How Legislators Predict Referendum Voting." American Journal of Political Science 19(2): 231-246.

Eulau, Heinz, and Paul D. Karps. 1977. "The Puzzle of Representation: Specifying Components of Responsiveness.” Legislative Studies Quarterly 2(3): 233-254.

Fenno, Richard F. 1978. Home Style: House Members in Their Districts. Boston: Little, Brown.

Fiorina, Morris. 1974. Representatives, Roll Call, and Constituencies. Lexington, MA: Lexington Books.

Freedman, David A. 2008. "On Regression Adjustments to Experimental Data." Advances in Applied Mathematics 40(2): 180-193.

Freeman, Patricia K., and Lilliard E. Richardson. 1996. "Explaining Variation in Casework among State Legislators.” Legislative Studies Quarterly 21(1): 41-56.

Fryer, Roland G., and Steven D. Levitt. 2004. "The Causes and Consequences of Distinctively Black Names." Quarterly Journal of Economics 119(3): 767-805.

Gamm, Gerald, and Thad Kousser. 2010. "Broad Bills or Particularistic Policy? Historical Patterns in American State Legislatures.” American Political Science Review 104(1): 151-170.

Gay, Claudine. 2002. "Spirals of Trust? The Effect of Descriptive Representation on the Relationship Between Citizens and Their Government." American Journal of Political Science 46(4): 717-732.

Gerber, Elisabeth R., and Jeffrey B. Lewis. 2004. "Beyond the Median: Voter Preferences, District Heterogeneity, and Political Representation.” Journal of Political Economy 112(6): 1364-1383.

Griffin, John D. 2006. "Electoral Competition and Democratic Responsiveness: A Defense of the Marginality Hypothesis.” Journal of Politics 68(4): 909-919.

Griffin, John D., and Michael Keane. 2006. "Descriptive Representation and the Composition of African American Turnout.” American Journal of Political Science 50(4): 998-1012.

Griffin, John D., and Patrick Flavin. 2007. "Racial Differences in Information, Expectations, and Accountability.” Journal of Politics 69(1): 220-236.

Griffin, John D., and Patrick Flavin. 2011. "How Citizens and Their Legislators Prioritize Spheres of Representation." Political Research Quarterly 64(3): 520-533.

Grimmer, Justin. 2012. "Appropriators not Statesmen: The Distorting Effects of Electoral Incentives on Congressional Representation." Working Paper, Stanford University.

Grose, Christian R. 2011. Congress in Black and White: Race and Representation in Washington and at Home. New York: Cambridge University Press.

Harden, Jeffrey J. 2011a. "A Bootstrap Method for Conducting Statistical Inference with Clustered Data." State Politics \& Policy Quarterly 11(2): 223-246. 
Harden, Jeffrey J. 2011b. "Multidimensional Democracy: Citizen Demand for the Components of Political Representation." Presented at the $11^{\text {th }}$ Annual State Politics and Policy Conference, Hanover, NH.

Harden, Jeffrey J., and Thomas M. Carsey. 2012. "Balancing Constituency Representation and Party Responsiveness in the U.S. Senate: The Conditioning Effect of State Ideological Heterogeneity." Public Choice 150(1-2): 137-154.

Hero, Rodney E., and Caroline J. Tolbert. 1995. "Latinos and Substantive Representation in the U.S. House of Representatives: Direct, Indirect, or Nonexistent?” American Journal of Political Science 39(3): 640-652.

Hibbing, John R., and John R. Alford. 1990. "Constituency Population and Representation in the U. S. Senate.” Legislative Studies Quarterly 15(4): 581-598.

Hogan, Robert E. 2008. "Policy Responsiveness and Incumbent Reelection in State Legislatures." American Journal of Political Science 52(4): 858-873.

Imai, Kosuke. 2011. "Multivariate Regression Analysis for the Item Count Technique." Journal of the American Statistical Association 106(494): 407-416.

Jaccard, James, and Robert Turrisi. 2003. Interaction Effects in Multiple Regression. Thousand Oaks, CA: Sage.

Jacobs, Lawrence R., and Robert Y. Shapiro. 2000. Politicians Don't Pander: Political Manipulation and the Loss of Democratic Responsiveness. Chicago: University of Chicago Press.

Jacobson, Gary C. 2004. The Politics of Congressional Elections. 6 ed. New York: Pearson Longman.

Johannes, John R. 1984. To Serve the People: Congress and Constituency Service. Lincoln, NE: University of Nebraska Press.

Kalton, Graham, and Ismael Flores-Cervantes. 2003. "Weighting Methods." Journal of Official Statistics 19(2): 81-97.

Kirkpatrick, Jeane J. 1974. Political Woman. New York: Basic Books.

Kousser, Thad, Jeffrey B. Lewis, and Seth E. Masket. 2007. "Ideological Adaptation? The Survival Instinct of Threatened Legislators." Journal of Politics 69(3): 828-843.

Lawless, Jennifer. 2004. "Politics of Presence? Congresswomen and Symbolic Representation." Political Research Quarterly 57(1): 81-99.

Lax, Jeffrey R., and Justin H. Phillips. 2012. "The Democratic Deficit in the States." American Journal of Political Science 56(1): 148-166.

Lazarus, Jeffrey. 2010. "Giving the People What they Want? The Distribution of Earmarks in the U.S. House of Representatives.” American Journal of Political Science 54(2): 338-353.

Levitt, Steven D. 1996. "How Do Senators Vote? Disentangling the Role of Voter Preferences, Party Affiliation, and Senator Ideology.” American Economic Review 86(3): 425-441.

Liang, Kung-Yee, and Scott L. Zeger. 1986. "Longitudinal Data Analysis Using Generalized Linear Models." Biometrika 73(1): 13-22.

Lowi, Theodore J. 1979. The End of Liberalism. New York: W.W. Norton \& Company.

MacRae, Duncan. 1952. "The Relation Between Roll Call Votes and Constituencies in the Massachusetts House of Representatives.” American Political Science Review 46(4): 1046-1055. 
Maestas, Cherie. 2000. "Professional Legislatures and Ambitious Politicians: Policy Responsiveness of State Institutions." Legislative Studies Quarterly 25(4): 663-690.

Maestas, Cherie. 2003. "The Incentive to Listen: Progressive Ambition, Resources, and Opinion Monitoring among State Legislators.” Journal of Politics 65(2): 439-456.

Mayhew, David R. 1974. Congress: The Electoral Connection. New Haven, CT: Yale University Press.

Meier, Kenneth J., Eric Gonzalez Juenke, Robert D. Wrinkle, and J. L. Polinard. 2005. "Structural Choices and Representational Biases: The Post-Election Color of Representation." American Journal of Political Science 49(4): 758-768.

Miller, Judith Droitcour. 1984. A New Survey Technique for Studying Deviant Behavior. PhD thesis George Washington University.

Miller, Warren E., and Donald E. Stokes. 1963. "Constituency Influence in Congress.” American Political Science Review 57(1): 45-56.

Oppenheimer, Bruce I. 1996. "The Representational Experience: The Effect of State Population on Senator-Constituency Linkages.” American Journal of Political Science 40(4): 1280-1299.

Page, Benjamin I., Robert Y. Shapiro, Paul W. Gronke, and Robert M. Rosenberg. 1984. "Constituency, Party, and Representation in Congress." Public Opinion Quarterly 48(4): 741-756.

Palmer, Barbara, and Dennis Simon. 2006. Breaking the Political Glass Ceiling: Women and Congressional Elections. New York: Routledge.

Patterson, Samuel C. 1962. "Dimensions of Voting Behavior in a One-Party State Legislature." Public Opinion Quarterly 26(2): 185-200.

Patterson, Samuel C. 1990. "State Legislators and their Legislatures." In Politics in the American States, ed. Virginia Gray, Herbert Jacob, and Robert B. Albritton. 5 ed. Glenview, IL: Little, Brown.

Preuhs, Robert R. 2006. "The Conditional Effects of Minority Descriptive Representation: Black Legislators and Policy Influence in the American States." Journal of Politics 68(3): 585-599.

Primo, David M. 2006. "Stop Us Before We Spend Again: Institutional Constraints on Government Spending." Economics \& Politics 18(3): 269-312.

Primo, David M., and James M. Snyder. 2008. "Distributive Politics and the Law of 1/n." Journal of Politics 70(2): 477-486.

Richardson, Lilliard E., and Patricia K. Freeman. 1995. "Gender Differences in Constituency Service Among State Legislators.” Political Research Quarterly 48(1): 169-179.

Riker, William H. 1986. The Art of Political Manipulation. New Haven, CT: Yale University Press.

Serra, George, and David Moon. 1994. "Casework, Issue Positions, and Voting in Congressional Elections: A District Analysis." Journal of Politics 56(1): 200-213.

Serra, George, and Neil Pinney. 2004. "Casework, Issues and Voting in State Legislative Elections: A District Analysis.” Journal of Legislative Studies 10(4): 32-46.

Squire, Peverill. 2000. "Uncontested Seats in State Legislative Elections." Legislative Studies Quarterly 25(1): 131-146.

Stein, Robert M., and Kenneth N. Bickers. 1995. Perpetuating the Pork Barrel: Policy Subsystems and American Democracy. New York: Cambridge University Press. 
Sulkin, Tracy. 2005. Issue Politics in Congress. New York: Cambridge University Press.

Swers, Michele L. 2002. The Difference Women Make: The Policy Impact of Women in Congress. Chicago: University of Chicago Press.

Tate, Katherine. 2001. "The Political Representation of Blacks in Congress: Does Race Matter?" Legislative Studies Quarterly 26(4): 623-638.

Tate, Katherine. 2003. Black Faces in the Mirror: African Americans and their Representatives in the U.S. Congress. Princeton, NJ: Princeton University Press.

Thomas, Sue. 1992. “The Effects of Race and Gender on Constituency Service.” Western Political Quarterly 45(1): 169-180.

Thomas, Sue. 1994. How Women Legislate. New York: Oxford University Press.

Verba, Sidney, and Norman H. Nie. 1972. Participation in America: Political Democracy and Social Equality. New York: Harper and Row.

Wahlke, John, Heinz Eulau, William Buchanan, and LeRoy C. Ferguson. 1962. The Legislative System. New York: Wiley.

Weingast, Barry R. 1979. "A Rational Choice Perspective on Congressional Norms.” American Journal of Political Science 23(1): 245-262.

Weingast, Barry R., Kenneth A. Shepsle, and Christopher Johnsen. 1981. "The Political Economy of Benefits and Costs: A Neoclassical Approach to Distributive Politics." Journal of Political Economy 89(4): 642-664. 


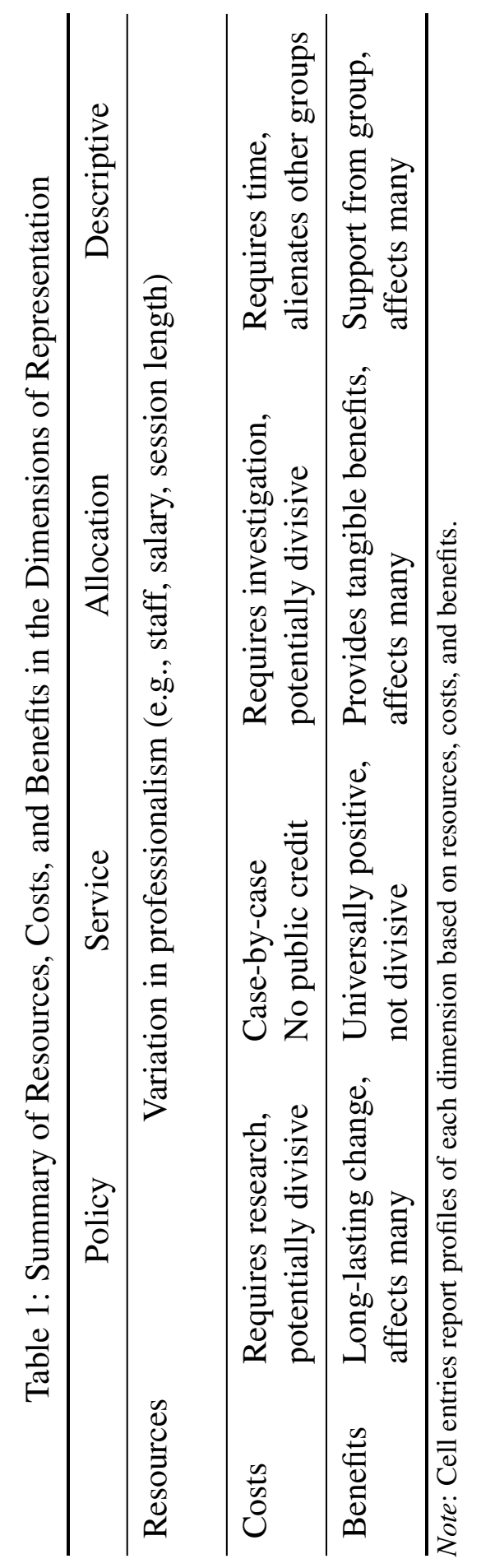


Table 2: Sample versus Population Comparisons on Key Respondent Variables

\begin{tabular}{lrrr}
\hline Variable & Sample Proportion & Population Proportion & Difference \\
\hline Republican & 0.52 & 0.54 & -0.02 \\
Female & 0.29 & 0.23 & $+0.06^{*}$ \\
Black & 0.04 & 0.09 & $-0.05^{*}$ \\
Latino/a & 0.02 & 0.03 & $-0.01^{*}$ \\
Upper Chamber & 0.23 & 0.27 & $-0.04^{*}$ \\
\hline
\end{tabular}

Note: Cell entries report sample and population proportions of each variable and the differences between the two. * Sample proportion is statistically significantly different from the population proportion $(p<0.05)$. 
Table 3: List Experiment Difference-in-Means Tests by Gender and Race

\begin{tabular}{rrrr}
\hline & Treatment & Control & Difference \\
\hline All Men & 3.42 & 3.05 & $0.37^{*}$ \\
All Women & 3.62 & 3.36 & $0.26^{*}$ \\
\hline All Whites & 3.42 & 3.11 & $0.31^{*}$ \\
All Blacks & 4.45 & 3.45 & $0.99^{*}$ \\
\hline
\end{tabular}

Note: Cell entries report treatment and control group means and differences. The control group viewed a list of five non-sensitive items. The treatment group viewed a list with six items: the same five non-sensitive items as the control group as well as the sensitive item. ${ }^{*} p<0.05$ (two-tailed). 
Table 4: List Experiment ICT Regression Results

\begin{tabular}{l|rr|rr}
\hline & \multicolumn{2}{c}{ Treatment } & \multicolumn{2}{c}{ Control } \\
\hline & Coefficient & SE & Coefficient & SE \\
\hline Black Legislator & -2.03 & 4.87 & $0.73^{*}$ & 0.31 \\
District \% Black & 0.00 & 0.03 & 0.00 & 0.00 \\
Black Legislator $\times$ District \% Black & 0.08 & 0.10 & $-0.01^{*}$ & 0.01 \\
Latino/a Legislator & 0.10 & 1.92 & 0.15 & 0.27 \\
Female Legislator & -0.23 & 0.76 & $0.22^{*}$ & 0.08 \\
Republican & -0.61 & 0.70 & $-0.14^{*}$ & 0.07 \\
Seniority & 0.04 & 0.05 & 0.01 & 0.00 \\
Electoral Competition & 0.01 & 0.02 & -0.00 & 0.00 \\
District Median Income & -0.05 & 0.03 & -0.00 & 0.00 \\
Multimember District & -0.59 & 0.86 & -0.01 & 0.08 \\
Professionalism & -3.24 & 3.30 & $1.06^{*}$ & 0.30 \\
Intercept & 2.76 & 1.95 & 0.31 & 0.18 \\
\hline$N$ & 516 & & 583 & \\
\hline
\end{tabular}

Note: Cell entries report ICT regression coefficients. A likelihood ratio test indicates no design effect (see Imai 2011 or footnote 12). ${ }^{*} p<0.05$ (two-tailed). 
Figure 1: Effects of Professionalism, Multimember Districts, Electoral Competition, and Likelihood of Satisfying Request in the Constituent E-mail Experiment

(a) Professionalism

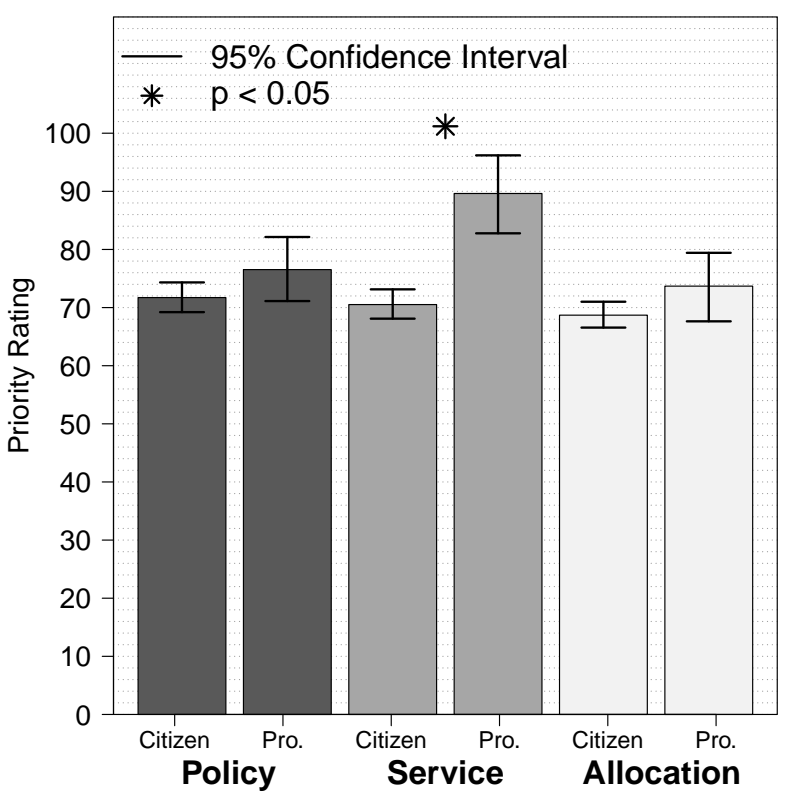

(c) Electoral Competition

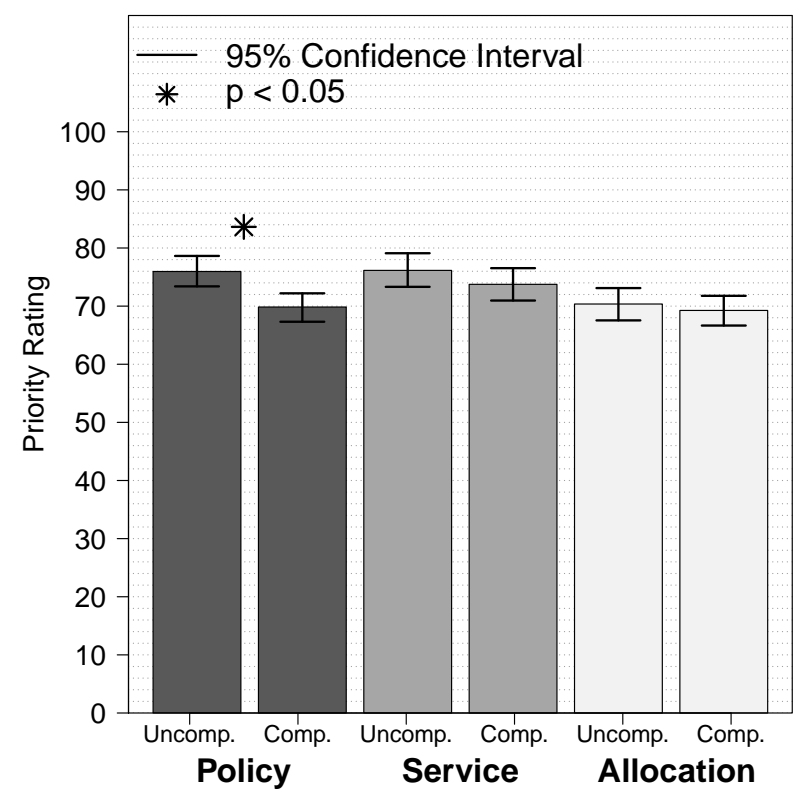

(b) Multimember Districts

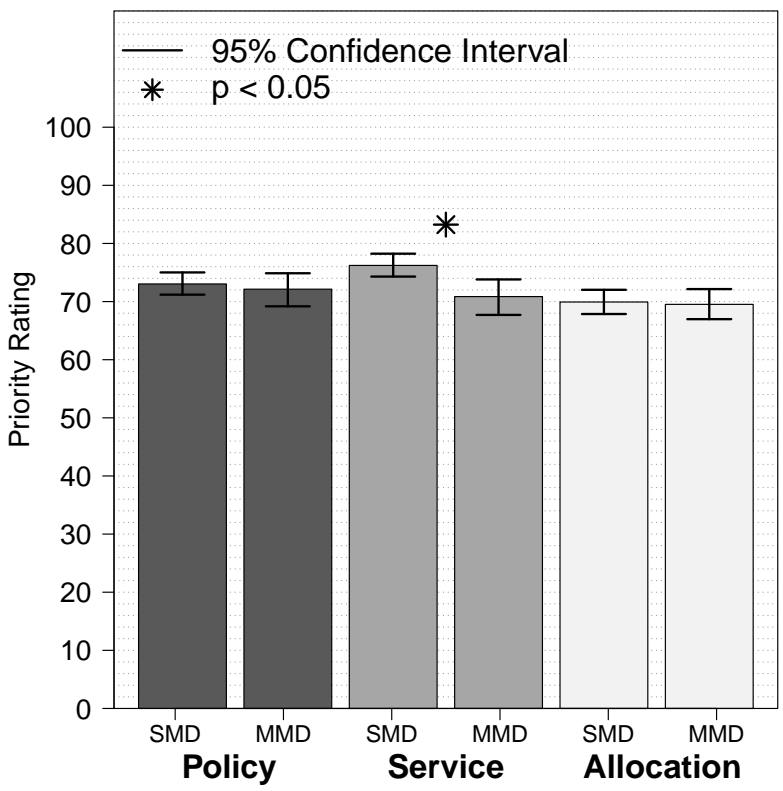

(d) Likelihood of Satisfying Request

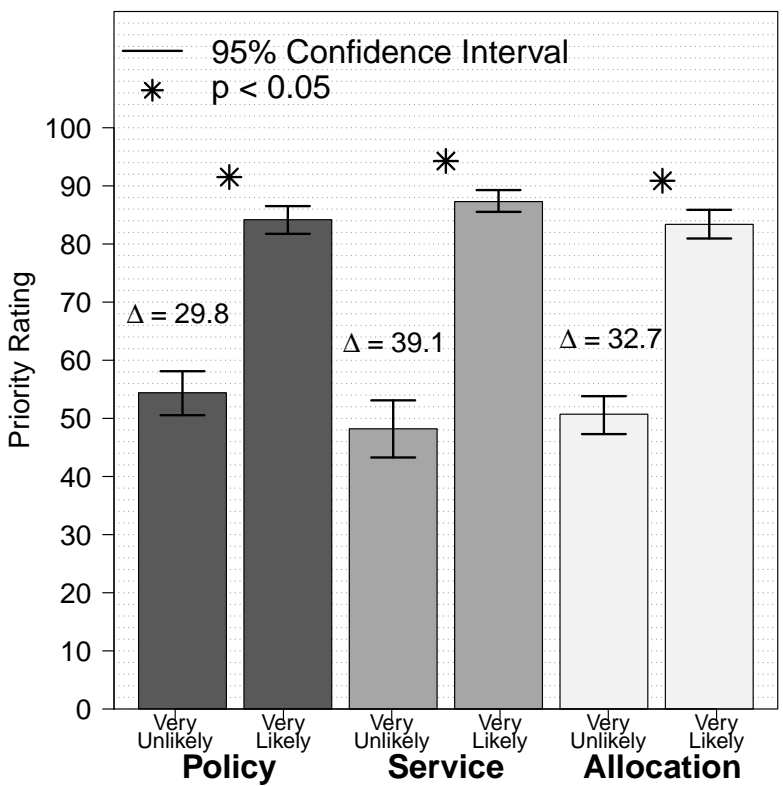

Note: The graphs present the average priority rating in each experimental condition by the minimum and maximum value of professionalism (panel a), single-member versus multimember districts (panel $b$ ), the minimum and maximum value of electoral competition (panel c), and a rating of very unlikely versus very likely to satisfy the constituent (panel d). ${ }^{*}$ Difference between two same-shaded bars is statistically significant at $p<0.05$ (two-tailed). 


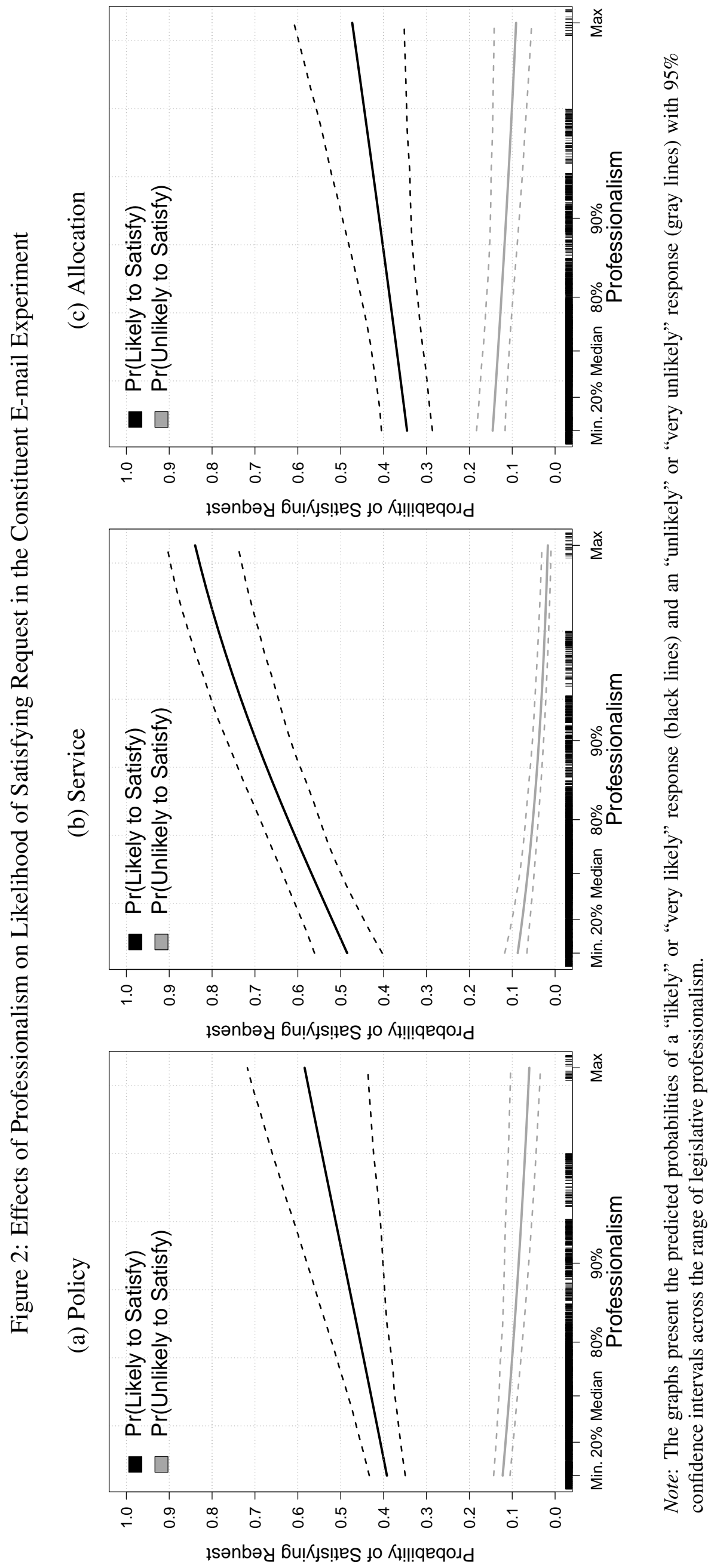




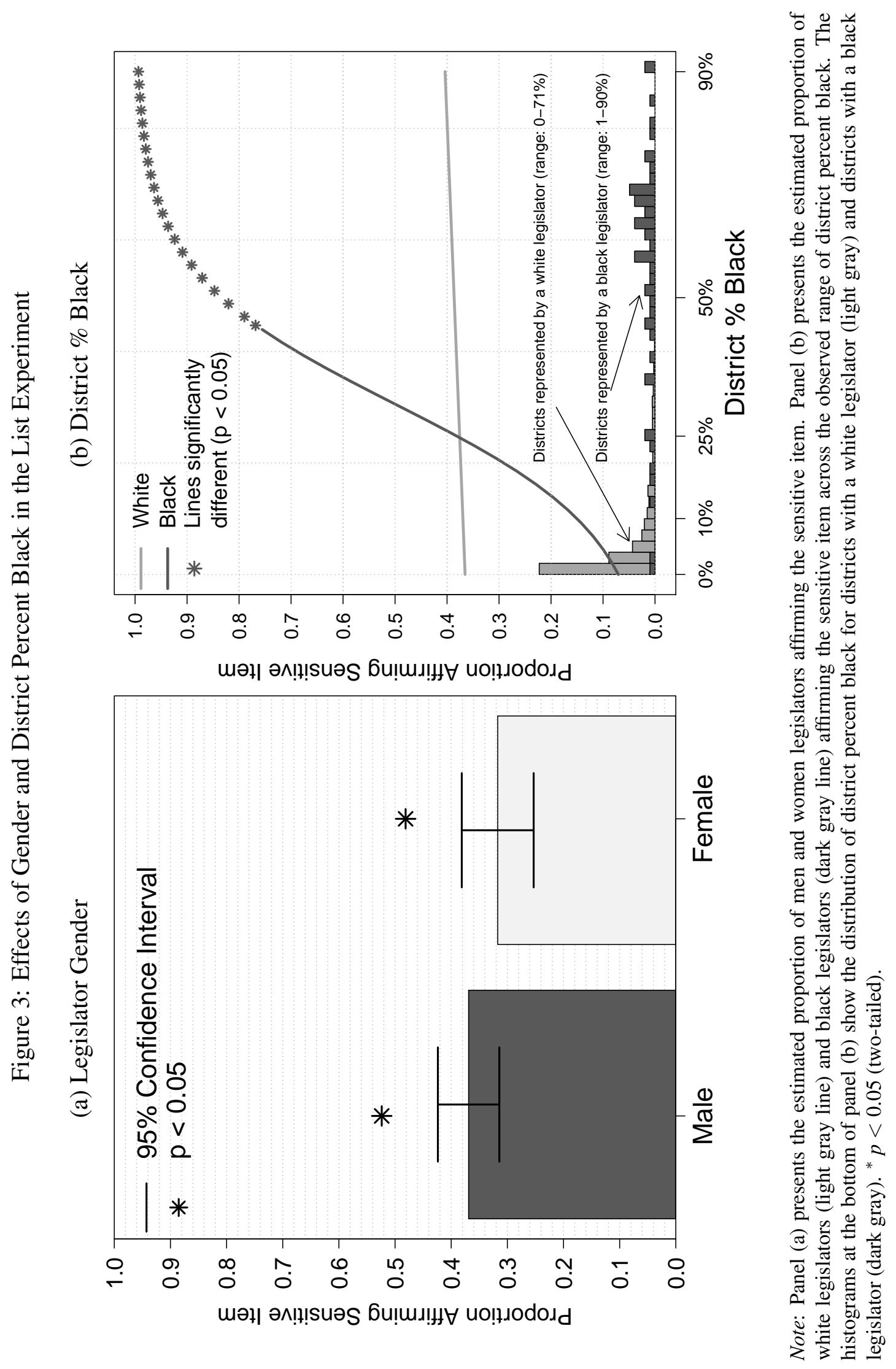




\title{
Multidimensional Responsiveness: The Determinants of Legislators' Representational Priorities
}

\author{
Appendix
}

\section{Contents}

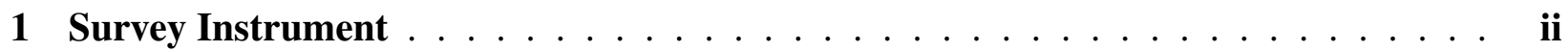

1.1 Constituent E-mail Experiment . . . . . . . . . . . . . ii

1.1.1 Experimental Design ......................... ii

1.2 List Experiment . . . . . . . . . . . . . . . . . iv

1.2.1 Control Group . . . . . . . . . . . . . . . . . iv

1.2.2 Treatment Group . . . . . . . . . . . . . . . . iv

2 Full State-Level Response Rates . . . . . . . . . . . . . . . . . . . . v

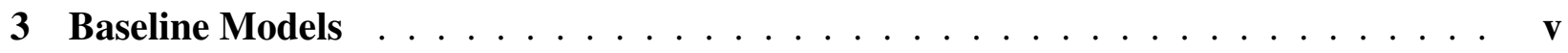

4 Complete Model Results . . . . . . . . . . . . . . . . . . . vi

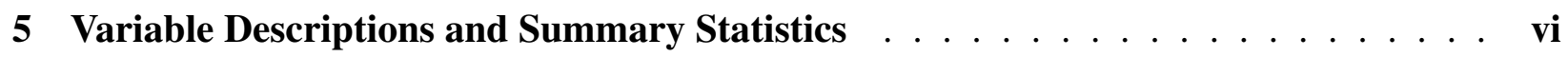




\section{Survey Instrument}

The complete text of the survey experiments is given below. Respondents viewed the constituent e-mail experiment first, then the list experiment.

\subsection{Constituent E-mail Experiment}

All respondents viewed the introductory text first, then were randomly presented with three messages: one each about policy, service, and allocation. The constituent's name was also randomized to signal gender and race. The randomized names are presented above each message by gender. The racial order is white, black, Latino/a.

\section{Introductory Text}

You will now see a series of three e-mail messages sent to you from hypothetical constituents. In each one, first read the message. Then answer two questions about each one. First, evaluate the priority level you or your office would give this e-mail if it were sent to you today. Select your evaluation by clicking on a number on the "priority scale" under the message. This measure ranges from 0 to 100 , with 0 indicating lowest priority and 100 indicating highest priority. If you would give the message average priority, select the score 50 . Second, evaluate how likely you would be able to satisfy the constituent.

\section{Policy Treatment}

- Male names: Connor Fredericks, Tyrone Baker, Juan Lopez

- Female names: Molly Wollsteiner, Shanice Jackson, Camila Garcia

\section{Dear Legislator,}

My name is [Name] and I want to ask you about public education in our state. I've been hearing how teachers might only get raises if their students get good test scores. Won't that just make teachers afraid to teach in poor schools? What do you think about this, and how do you see it affecting our state?

Thanks, [Name] 
Service Treatment

- Male names: Jacob Nichols, DeAndre Moore, Antonio Ruiz

- Female names: Amy Schneider, Tasheka Robinson, Gabriela Mendez

Dear Legislator,

My name is [Name] and I am having some problems getting a driver's license. The people at the driver's license office say I can't prove I am a resident of the state, but that's not true! I am a resident of the state! I am really tired of dealing with this. Is there anything you can do for me?

Thanks,

[Name]

\section{Allocation Treatment}

- Male names: Luke Jacobsen, Terrell Washington, Eduardo Diaz

- Female names: Claire Neilsson, Denisha Jones, Marina Gutierrez

Dear Legislator,

My name is [Name] and I am concerned about whether our district will be getting any money for road repair this year. I am so tired of all the potholes! Will we be getting any state money, or maybe some Federal stimulus money? I know you have to drive on these roads too!

Thanks, [Name]

After each e-mail, respondents answered the following two questions:

(1) What priority level would you give this e-mail? You may choose any number from 0 to 100.0 = Lowest priority; $50=$ Average priority; $100=$ Highest priority [0-100 Slide Bar]

(2) Based only on the information given in the e-mail, how likely is it that you could satisfy this constituent?

$\circ$ Very Unlikely

○ Unlikely

- Somewhat Unlikely

- Somewhat Likely

- Likely

○ Very Likely

\subsubsection{Experimental Design}

The table below summarizes the randomization of respondents to treatment conditions in the constituent e-mail experiment. Recall that each respondent viewed a total of three messages-a 
policy, service, and allocation treatment-in random order. Several balance checks (not shown) confirmed no systematic patterns in treatment assignments due to several respondent traits.

\begin{tabular}{|l|c|c|c|}
\hline Constituent gender/race... & Policy E-mail & Service E-mail & Allocation E-mail \\
\hline White Male & $n=398$ & $n=462$ & $n=447$ \\
\hline Black Male & $n=469$ & $n=477$ & $n=438$ \\
\hline Latino Male & $n=438$ & $n=418$ & $n=466$ \\
\hline White Female & $n=524$ & $n=439$ & $n=521$ \\
\hline Black Female & $n=441$ & $n=444$ & $n=443$ \\
\hline Latina Female & $n=423$ & $n=453$ & $n=378$ \\
\hline
\end{tabular}

\subsection{List Experiment}

All respondents viewed the introductory text first, then were randomly assigned to the control or treatment group.

\section{Introductory Text}

Next you will see a list of some activities that occupy political representatives as part of their job. Think about HOW MANY of these items are important to you as a legislator (or to the legislator you work for). You will not need to say which ones, just how many.

\subsubsection{Control Group}

The control group ( $n=583$ ) saw the five non-sensitive items in random order:

(1) Learning about constituents' opinions in order to better represent their views.

(2) Helping constituents who have personal problems with government agencies.

(3) Making sure the district gets its fair share of government money and projects.

(4) Preparing to run for higher office, such as Governor or the U.S. Congress.

(5) Representing the views of interest groups.

\subsubsection{Treatment Group}

The treatment group $(n=516)$ saw the same non-sensitive items as the control group as well as the the sensitive item, all in random order: 
(1) Learning about constituents' opinions in order to better represent their views.

(2) Helping constituents who have personal problems with government agencies.

(3) Making sure the district gets its fair share of government money and projects.

(4) Preparing to run for higher office, such as Governor or the U.S. Congress.

(5) Representing the views of interest groups.

(6) Making sure that people who are of the same gender or race as you have their voices heard in government.

\section{Full State-Level Response Rates}

Table A.1 presents the full state-level response rates. The first column reports the number of responses from each state and the second column reports the total number of legislators in the state's legislature. The third column reports the state-level response rate (i.e., column $1 \div$ column 2). The fourth column reports the proportion of the usable sample from each state, while the fifth gives the proportion of the entire population of state legislators $(7,382)$ from that state's legislature. Finally, the sixth column reports the ratio of the sample proportion to the population proportion (i.e., column $4 \div$ column 5 ). States with numbers greater than one are overrepresented compared to their population value, while states with values smaller than one are underrepresented.

The response rate by state varied from a low of $7 \%$ (California, Mississippi, and Pennsylvania) to a high of $30 \%$ (Delaware and Vermont). Ten states were underrepresented by 0.50 compared to their population proportions while Vermont was the most overrepresented, by a factor of 2.50 .

[Insert Table A.1 here]

\section{Baseline Models}

Figure A.1 displays the baseline treatment effects from the constituent e-mail experiment. In each graph the $\mathrm{x}$-axis plots the experimental conditions and the $\mathrm{y}$-axis plots the priority rating. Within each message treatment (policy, service, and allocation), results are given for the male and female constituent names. Panel (a) gives results for the white constituent names, panel (b) gives results for the black constituent names, and panel (c) gives results for the Latino/a constituent 
names. Solid lines indicate $95 \%$ confidence intervals.

[Insert Figure A.1 here]

The average priority rating in the constituent e-mail experiment is 71 with a standard deviation of 22. The graphs show that on average, legislators rated the service condition a higher priority than the policy condition and the policy condition slightly higher than the allocation condition. All three panels show very small differences in the average response to the different racial cue names. Furthermore, within each panel there are only small differences in priority ratings by the different constituent genders.

\section{Complete Model Results}

Tables A.2 and A.3 present complete model results from the constituent e-mail experiment.

[Insert Table A.2 here]

[Insert Table A.3 here]

\section{Variable Descriptions and Summary Statistics}

Table A.4 presents variable descriptions and summary statistics and Table A.5 reports pairwise correlations between the independent variables.

[Insert Table A.4 here]

[Insert Table A.5 here]

\section{References}

Harden, Jeffrey J. 2011. "A Bootstrap Method for Conducting Statistical Inference with Clustered Data." State Politics \& Policy Quarterly 11(2): 223-246.

Kalton, Graham, and Ismael Flores-Cervantes. 2003. "Weighting Methods." Journal of Official Statistics 19(2): 81-97.

Squire, Peverill. 2000. "Uncontested Seats in State Legislative Elections." Legislative Studies Quarterly 25(1): 131-146. 


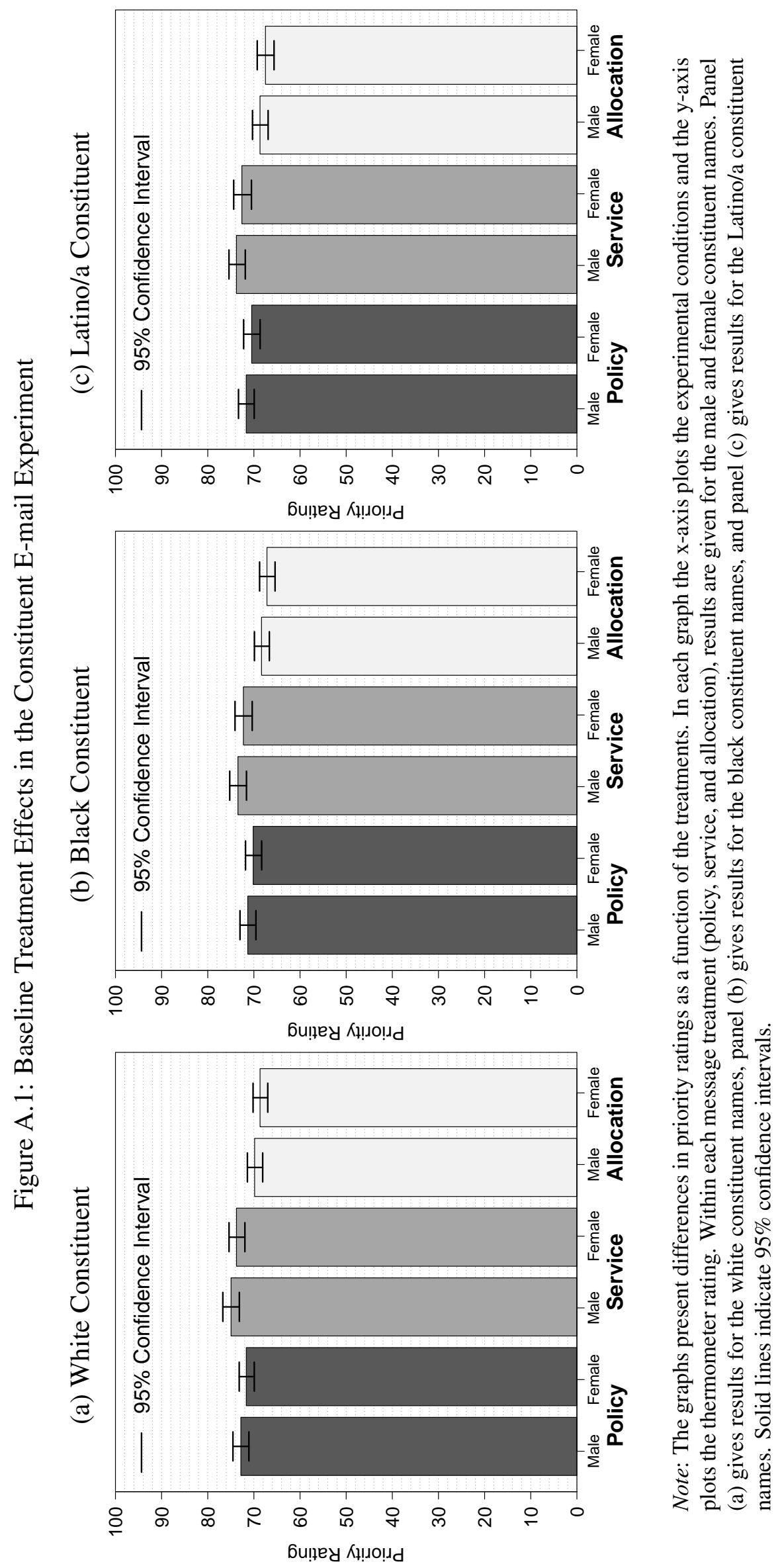


Table A.1: Full State-Level Response Rates

\begin{tabular}{|c|c|c|c|c|c|c|}
\hline State & $\begin{array}{l}\text { Sample } \\
\text { Size }\end{array}$ & $\begin{array}{l}\text { Legislature } \\
\text { Size }\end{array}$ & $\begin{array}{l}\text { State Response } \\
\text { Rate }\end{array}$ & $\begin{array}{l}\text { Sample } \\
\text { Proportion }\end{array}$ & $\begin{array}{l}\text { Population } \\
\text { Proportion }\end{array}$ & $\begin{array}{l}\text { Sample/Pop. } \\
\text { Ratio }\end{array}$ \\
\hline Alabama & 24 & 140 & 0.17 & 0.02 & 0.02 & 1.00 \\
\hline Alaska & 15 & 60 & 0.25 & 0.01 & 0.01 & 1.00 \\
\hline Arizona & 13 & 90 & 0.14 & 0.01 & 0.01 & 1.00 \\
\hline Arkansas & 27 & 135 & 0.20 & 0.02 & 0.02 & 1.00 \\
\hline California & 8 & 120 & 0.07 & 0.01 & 0.02 & 0.50 \\
\hline Colorado & 22 & 100 & 0.22 & 0.02 & 0.01 & 2.00 \\
\hline Connecticut & 20 & 187 & 0.11 & 0.02 & 0.03 & 0.67 \\
\hline Delaware & 19 & 62 & 0.31 & 0.02 & 0.01 & 2.00 \\
\hline Florida & 15 & 160 & 0.09 & 0.01 & 0.02 & 0.50 \\
\hline Georgia & 23 & 236 & 0.10 & 0.02 & 0.03 & 0.67 \\
\hline Hawaii & 9 & 76 & 0.12 & 0.01 & 0.01 & 1.00 \\
\hline Illinois & 31 & 177 & 0.18 & 0.03 & 0.02 & 1.50 \\
\hline Indiana & 21 & 150 & 0.14 & 0.02 & 0.02 & 1.00 \\
\hline Iowa & 28 & 150 & 0.19 & 0.02 & 0.02 & 1.00 \\
\hline Kansas & 25 & 165 & 0.15 & 0.02 & 0.02 & 1.00 \\
\hline Kentucky & 14 & 138 & 0.10 & 0.01 & 0.02 & 0.50 \\
\hline Louisiana & 26 & 144 & 0.18 & 0.02 & 0.02 & 1.00 \\
\hline Maine & 49 & 186 & 0.26 & 0.04 & 0.03 & 1.33 \\
\hline Maryland & 33 & 188 & 0.18 & 0.03 & 0.03 & 1.00 \\
\hline Massachusetts & 43 & 200 & 0.22 & 0.04 & 0.03 & 1.33 \\
\hline Michigan & 23 & 148 & 0.16 & 0.02 & 0.02 & 1.00 \\
\hline Minnesota & 30 & 201 & 0.15 & 0.03 & 0.03 & 1.00 \\
\hline Mississippi & 13 & 174 & 0.07 & 0.01 & 0.02 & 0.50 \\
\hline Missouri & 35 & 197 & 0.18 & 0.03 & 0.03 & 1.00 \\
\hline Montana & 17 & 150 & 0.11 & 0.01 & 0.02 & 0.50 \\
\hline Nebraska & 11 & 49 & 0.22 & 0.01 & 0.01 & 1.00 \\
\hline Nevada & 15 & 63 & 0.24 & 0.01 & 0.01 & 1.00 \\
\hline New Hampshire & 114 & 424 & 0.27 & 0.10 & 0.06 & 1.67 \\
\hline New Jersey & 13 & 120 & 0.11 & 0.01 & 0.02 & 0.50 \\
\hline New Mexico & 14 & 112 & 0.13 & 0.01 & 0.02 & 0.50 \\
\hline New York & 25 & 212 & 0.12 & 0.02 & 0.03 & 0.67 \\
\hline North Carolina & 48 & 170 & 0.28 & 0.04 & 0.02 & 2.00 \\
\hline North Dakota & 40 & 141 & 0.28 & 0.03 & 0.02 & 1.50 \\
\hline Ohio & 18 & 132 & 0.14 & 0.02 & 0.02 & 1.00 \\
\hline Oklahoma & 20 & 149 & 0.13 & 0.02 & 0.02 & 1.00 \\
\hline Oregon & 27 & 90 & 0.30 & 0.02 & 0.01 & 2.00 \\
\hline Pennsylvania & 18 & 253 & 0.07 & 0.02 & 0.03 & 0.67 \\
\hline Rhode Island & 9 & 113 & 0.08 & 0.01 & 0.02 & 0.50 \\
\hline Tennessee & 17 & 132 & 0.13 & 0.01 & 0.02 & 0.50 \\
\hline Utah & 22 & 104 & 0.21 & 0.02 & 0.01 & 2.00 \\
\hline Vermont & 56 & 180 & 0.31 & 0.05 & 0.02 & 2.50 \\
\hline Virginia & 34 & 140 & 0.24 & 0.03 & 0.02 & 1.50 \\
\hline Washington & 24 & 147 & 0.16 & 0.02 & 0.02 & 1.00 \\
\hline West Virginia & 31 & 134 & 0.23 & 0.03 & 0.02 & 1.50 \\
\hline Wisconsin & 10 & 132 & 0.08 & 0.01 & 0.02 & 0.50 \\
\hline Wyoming & 26 & 90 & 0.29 & 0.02 & 0.01 & 2.00 \\
\hline
\end{tabular}


Table A.2: Complete Results from the Constituent E-mail Experiment

\begin{tabular}{|c|c|c|c|c|c|c|c|c|c|}
\hline & Pro. & Legis. Size & District Med. Inc. & MMD & Elec. Comp. & Gender & Race & Satisfy & Full \\
\hline Intercept & $\begin{array}{r}71.51^{*} \\
(1.38)\end{array}$ & $\begin{array}{r}75.08^{*} \\
(1.62)\end{array}$ & $\begin{array}{r}76.58^{*} \\
(2.17)\end{array}$ & $\begin{array}{r}73.03^{*} \\
(0.98)\end{array}$ & $\begin{array}{r}64.93^{*} \\
(2.77)\end{array}$ & $\begin{array}{r}72.07^{*} \\
(1.03)\end{array}$ & $\begin{array}{r}71.86^{*} \\
(0.93)\end{array}$ & $\begin{array}{r}48.46^{*} \\
(2.55)\end{array}$ & $\begin{array}{r}52.19^{*} \\
(8.60)\end{array}$ \\
\hline Service Treatment & $\begin{array}{r}-1.85 \\
(1.49)\end{array}$ & $\begin{array}{l}3.52^{*} \\
(1.78)\end{array}$ & $\begin{array}{r}-0.44 \\
(2.31)\end{array}$ & $\begin{array}{l}3.19^{*} \\
(0.84)\end{array}$ & $\begin{array}{l}6.89^{*} \\
(2.95)\end{array}$ & $\begin{array}{l}2.13^{*} \\
(0.74)\end{array}$ & $\begin{array}{l}2.18^{*} \\
(0.74)\end{array}$ & $\begin{array}{r}-8.07^{*} \\
(3.50)\end{array}$ & $\begin{array}{r}-13.51 \\
(8.66)\end{array}$ \\
\hline Allocation Treatment & $\begin{array}{r}-3.04^{*} \\
(1.24)\end{array}$ & $\begin{array}{r}0.13 \\
(1.44)\end{array}$ & $\begin{array}{r}-8.34^{*} \\
(2.10)\end{array}$ & $\begin{array}{r}-3.10^{*} \\
(0.738)\end{array}$ & $\begin{array}{r}3.44 \\
(2.62)\end{array}$ & $\begin{array}{r}-2.98^{*} \\
(0.64)\end{array}$ & $\begin{array}{r}-2.92^{*} \\
(0.63)\end{array}$ & $\begin{array}{l}-4.27 \\
(2.72)\end{array}$ & $\begin{array}{r}8.21 \\
(7.85)\end{array}$ \\
\hline Female Constituent & $\begin{array}{l}-1.16 \\
(0.70)\end{array}$ & $\begin{array}{l}-1.18 \\
(0.70)\end{array}$ & $\begin{array}{r}-1.17 \\
(0.70)\end{array}$ & $\begin{array}{l}-1.21 \\
(0.70)\end{array}$ & $\begin{array}{l}-1.11 \\
(0.70)\end{array}$ & $\begin{array}{r}-1.06 \\
(0.83)\end{array}$ & $\begin{array}{l}-1.09 \\
(0.70)\end{array}$ & $\begin{array}{r}-0.82 \\
(0.62)\end{array}$ & $\begin{array}{r}-1.04 \\
(0.73)\end{array}$ \\
\hline Black Constituent & $\begin{array}{l}-1.50 \\
(0.79)\end{array}$ & $\begin{array}{l}-1.50 \\
(0.79)\end{array}$ & $\begin{array}{r}-1.52 \\
(0.80)\end{array}$ & $\begin{array}{r}-1.48 \\
(0.79)\end{array}$ & $\begin{array}{r}-1.45 \\
(0.79)\end{array}$ & $\begin{array}{l}-1.47 \\
(0.79)\end{array}$ & $\begin{array}{r}-0.94 \\
(0.80)\end{array}$ & $\begin{array}{r}-1.72^{*} \\
(0.70)\end{array}$ & $\begin{array}{r}-1.55^{*} \\
(0.69)\end{array}$ \\
\hline Latino/a Constituent & $\begin{array}{r}-1.26 \\
(0.80)\end{array}$ & $\begin{array}{r}-1.22 \\
(0.80)\end{array}$ & $\begin{array}{r}-1.15 \\
(0.80)\end{array}$ & $\begin{array}{r}-1.12 \\
(0.80)\end{array}$ & $\begin{array}{r}-1.16 \\
(0.80)\end{array}$ & $\begin{array}{r}-1.13 \\
(0.80)\end{array}$ & $\begin{array}{r}-0.62 \\
(0.83)\end{array}$ & $\begin{array}{l}-0.64 \\
(0.72)\end{array}$ & $\begin{array}{r}-0.22 \\
(0.72)\end{array}$ \\
\hline Professionalism & $\begin{array}{r}8.04 \\
(5.90)\end{array}$ & & & & & & & & $\begin{array}{r}3.31 \\
(7.08)\end{array}$ \\
\hline Service $\times$ Pro & $\begin{array}{r}23.87^{*} \\
(7.22)\end{array}$ & & & & & & & & $\begin{array}{r}7.53 \\
(7.52)\end{array}$ \\
\hline Allocation $\times$ Pro. & $\begin{array}{r}0.303 \\
(5.92)\end{array}$ & & & & & & & & $\begin{array}{r}-0.18 \\
(5.98)\end{array}$ \\
\hline Legis. Size & & $\begin{array}{r}-0.01 \\
(0.01)\end{array}$ & & & & & & & $\begin{array}{r}-0.01 \\
(0.01)\end{array}$ \\
\hline Service $\times$ Legis. Size & & $\begin{array}{r}-0.01 \\
(0.01)\end{array}$ & & & & & & & $\begin{array}{r}0.00 \\
(0.01)\end{array}$ \\
\hline Allocation $\times$ Legis. Size & & $\begin{array}{r}-0.02^{*} \\
(0.01)\end{array}$ & & & & & & & $\begin{array}{r}-0.02^{*} \\
(0.01)\end{array}$ \\
\hline District Median Income & & & $\begin{aligned}-0.07^{*} \\
(0.04)\end{aligned}$ & & & & & & $\begin{array}{r}-0.01 \\
(0.04)\end{array}$ \\
\hline Service $\times$ Med. Inc. & & & $\begin{array}{r}0.05 \\
(0.04)\end{array}$ & & & & & & $\begin{array}{r}0.03 \\
(0.04)\end{array}$ \\
\hline Allocation $\times$ Med. Inc. & & & $\begin{array}{l}0.10^{*} \\
(0.04)\end{array}$ & & & & & & $\begin{array}{r}0.06 \\
(0.03)\end{array}$ \\
\hline Multimember District & & & & $\begin{array}{r}-0.90 \\
(1.62)\end{array}$ & & & & & $\begin{array}{r}1.19 \\
(1.65)\end{array}$ \\
\hline Service $\times$ MMD & & & & $\begin{array}{r}-4.46^{*} \\
(1.80)\end{array}$ & & & & & $\begin{array}{r}-4.83^{*} \\
(1.77)\end{array}$ \\
\hline Allocation $\times$ MMD & & & & $\begin{array}{r}0.49 \\
(1.49)\end{array}$ & & & & & $\begin{array}{r}1.18 \\
(1.59)\end{array}$ \\
\hline Electoral Competition & & & & & $\begin{array}{r}-0.11^{*} \\
(0.04)\end{array}$ & & & & $\begin{array}{r}-0.10^{*} \\
(0.04)\end{array}$ \\
\hline Service $\times$ Comp & & & & & $\begin{array}{r}0.07 \\
(0.04)\end{array}$ & & & & $\begin{array}{l}0.11^{*} \\
(0.04)\end{array}$ \\
\hline Allocation $\times$ Comp & & & & & $\begin{array}{l}0.09^{*} \\
(0.04)\end{array}$ & & & & $\begin{array}{r}0.07 \\
(0.03)\end{array}$ \\
\hline Female Legislator & & & & & & $\begin{array}{l}3.09^{*} \\
(1.48)\end{array}$ & & & $\begin{array}{r}1.27 \\
(1.33)\end{array}$ \\
\hline Female Legislator $\times$ Female Constituent & & & & & & $\begin{array}{r}-0.47 \\
(1.50)\end{array}$ & & & $\begin{array}{r}1.26 \\
(1.30)\end{array}$ \\
\hline Black Legislator & & & & & & & $\begin{array}{r}11.74^{*} \\
(2.68)\end{array}$ & & $\begin{array}{r}4.94 \\
(2.87)\end{array}$ \\
\hline Latino/a Legislator & & & & & & & $\begin{array}{r}1.77 \\
(4.85)\end{array}$ & & $\begin{array}{r}2.00 \\
(4.75)\end{array}$ \\
\hline Black Legislator $\times$ Black Constituent & & & & & & & $\begin{array}{r}-9.19^{*} \\
(3.35)\end{array}$ & & $\begin{array}{r}-2.77 \\
(3.45)\end{array}$ \\
\hline Latino/a Legislator $\times$ Black Constituent & & & & & & & $\begin{array}{r}1.98 \\
(6.25)\end{array}$ & & $\begin{array}{r}-1.62 \\
(5.44)\end{array}$ \\
\hline Black Legislator $\times$ Latino/a Constituent & & & & & & & $\begin{array}{r}-9.00^{*} \\
(3.15)\end{array}$ & & $\begin{array}{r}-6.54 \\
(3.42)\end{array}$ \\
\hline Latino/a Legislator $\times$ Latino/a Constituent & & & & & & & $\begin{array}{r}1.03 \\
(5.08)\end{array}$ & & $\begin{array}{r}-0.06 \\
(4.54)\end{array}$ \\
\hline Satisfy & & & & & & & & $\begin{array}{l}5.95^{*} \\
(0.55)\end{array}$ & $\begin{array}{l}5.92^{*} \\
(0.55)\end{array}$ \\
\hline Service $\times$ Satisfy & & & & & & & & $\begin{array}{l}1.86^{*} \\
(0.75)\end{array}$ & $\begin{array}{l}1.69^{*} \\
(0.74)\end{array}$ \\
\hline Allocation $\times$ Satisfy & & & & & & & & $\begin{array}{r}0.58 \\
(0.63)\end{array}$ & $\begin{array}{r}0.39 \\
(0.62)\end{array}$ \\
\hline Republican & & & & & & & & & $\begin{array}{r}-1.02 \\
(1.37)\end{array}$ \\
\hline Log(District Pop.) & & & & & & & & & $\begin{array}{r}-0.87 \\
(0.74)\end{array}$ \\
\hline Service $\times \log ($ Pop. $)$ & & & & & & & & & $\begin{array}{r}1.10 \\
(0.75)\end{array}$ \\
\hline Service $\times$ Republican & & & & & & & & & $\begin{array}{r}-0.82 \\
(1.34)\end{array}$ \\
\hline Allocation $\times \log ($ Pop. $)$ & & & & & & & & & $\begin{array}{r}-0.57 \\
(0.65)\end{array}$ \\
\hline Allocation $\times$ Republican & & & & & & & & & $\begin{array}{r}-0.04 \\
(1.22)\end{array}$ \\
\hline Observations & 3079 & 3079 & 3079 & 3079 & 3079 & 3079 & 3079 & 3070 & 3070 \\
\hline Legislators & 1065 & 1065 & 1065 & 1065 & 1065 & 1065 & 1065 & 1061 & 1061 \\
\hline
\end{tabular}

Note: Cell entries report GEE coefficients and standard errors (in parentheses) from the constituent e-mail experiment. The dependent variable is the priority rating of the e-mail. Data are weighted via raking to reflect state legislator population marginals on partisanship, chamber, gender, and race (see Kalton and Flores-Cervantes 2003). ${ }^{*} p<0.05$ (two-tailed). 
Table A.3: Ordered Logistic Regression Model of the Likelihood of Satisfying Request in the Constituent E-mail Experiment

\begin{tabular}{lrrrr}
\hline & $\beta$ & $\mathrm{SE}$ & $t$ & $p$ \\
\hline Service Condition & 0.34 & 0.13 & 2.51 & 0.01 \\
Allocation Condition & -0.19 & 0.11 & -1.76 & 0.08 \\
Female Constituent & -0.09 & 0.06 & -1.49 & 0.14 \\
Black Constituent & 0.08 & 0.07 & 1.15 & 0.25 \\
Latino/a Constituent & -0.14 & 0.07 & -2.04 & 0.04 \\
Female Legislator & -0.01 & 0.09 & -0.09 & 0.93 \\
Black Legislator & 0.07 & 0.22 & 0.33 & 0.74 \\
Latino/a Legislator & 0.04 & 0.33 & 0.13 & 0.90 \\
Republican Legislator & -0.26 & 0.08 & -3.48 & 0.00 \\
Professionalism & 1.30 & 0.45 & 2.87 & 0.00 \\
Service $\times$ Professionalism & 1.57 & 0.66 & 2.38 & 0.02 \\
Allocation $\times$ Professionalism & -0.41 & 0.55 & -0.75 & 0.45 \\
\hline Cut Points & & & & \\
\hline Very Unlikely | Unlikely & 3.26 & 0.16 & 20.83 & 0.00 \\
Unlikely | Somewhat Unlikely & 1.95 & 0.13 & 15.28 & 0.00 \\
Somewhat Unlikely | Somewhat Likely & 0.96 & 0.12 & 7.84 & 0.00 \\
Somewhat Likely | Likely & -0.46 & 0.12 & -3.74 & 0.00 \\
Likely | Very Likely & -2.07 & 0.13 & -15.81 & 0.00 \\
\hline Note Celly
\end{tabular}

Note: Cell entries report ordered logistic regression coefficients $(\beta)$, standard errors (SE), $t$-statistics, and $p$-values from the constituent e-mail experiment. The dependent variable is the likelihood of satisfying the constituent. Standard errors are computed via the bootstrap cluster method to account for within-respondent correlation (see Harden 2011). Data are weighted via raking to reflect state legislator population marginals on partisanship, chamber, gender, and race (see Kalton and Flores-Cervantes 2003). 


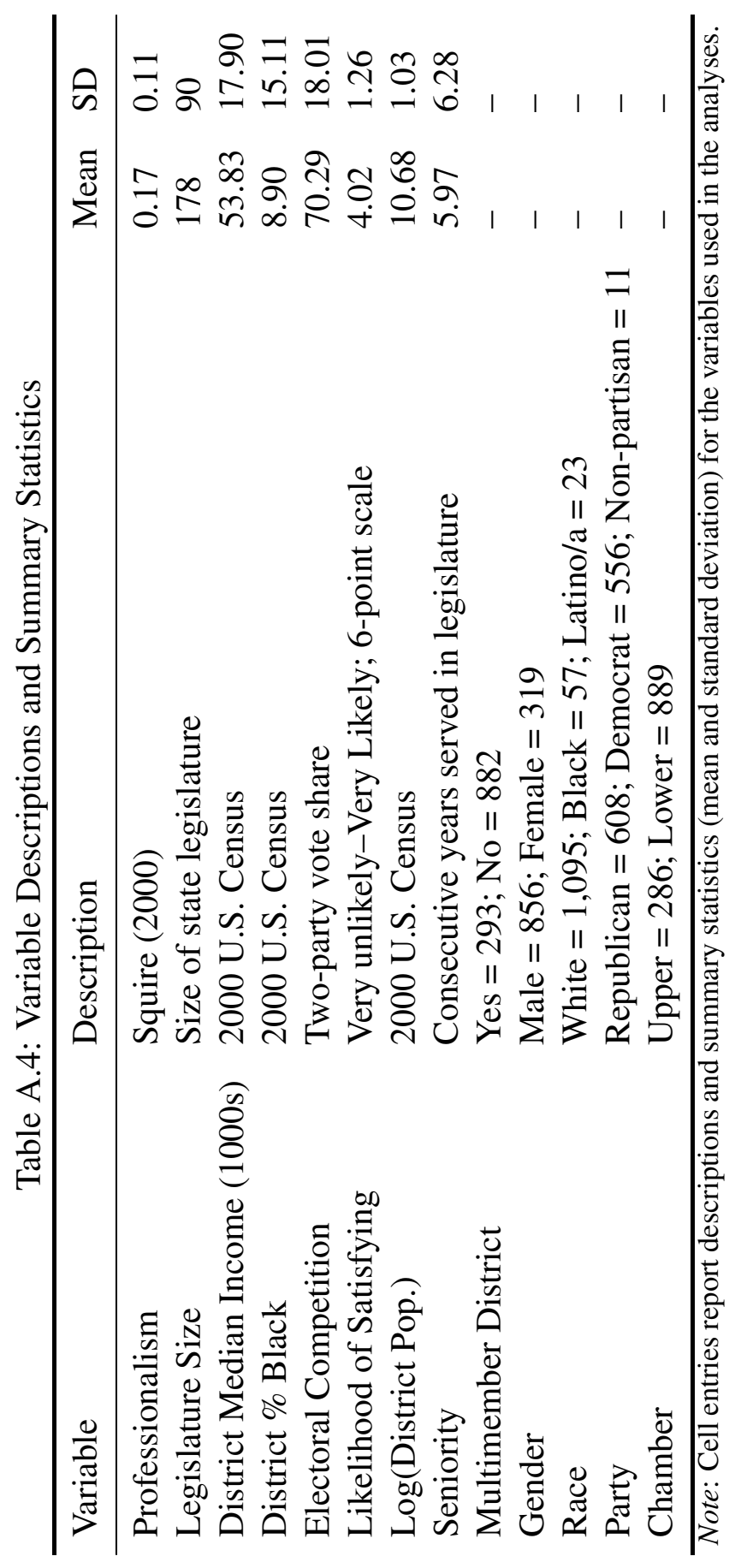




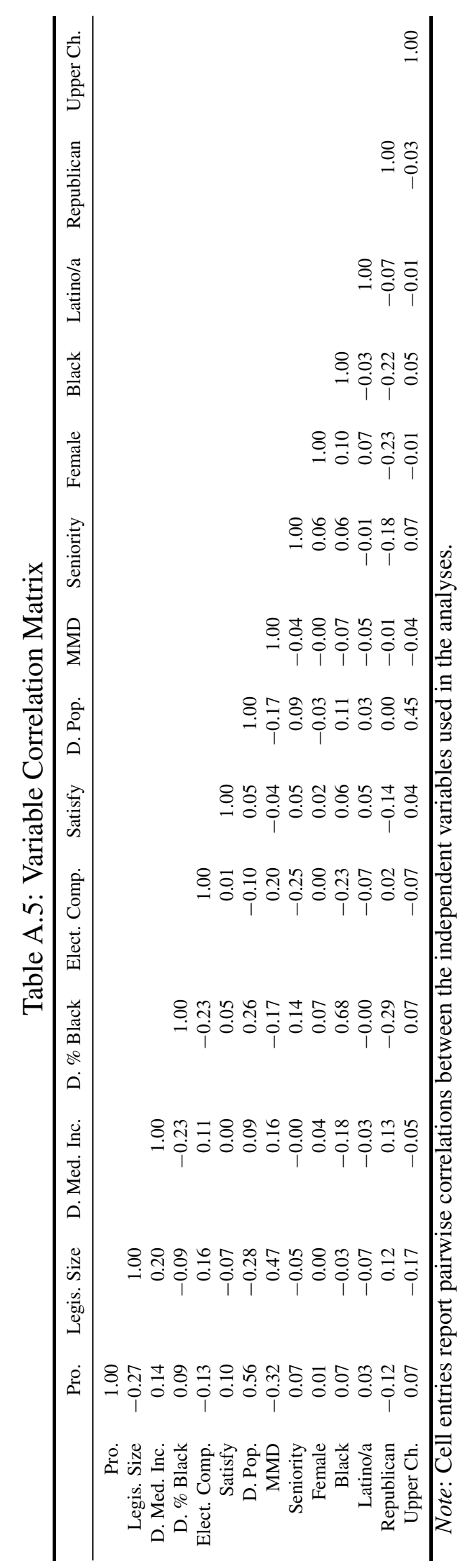

